Original article

\title{
Composition and nutritive value of whole maize plants fed fresh to sheep. I. Factors of variation
}

\author{
J Andrieu 1, C Demarquilly 1, P Dardenne 2, Y Barrière 3, \\ M Lila 3, P Maupetit 4, F Rivière 5, N Femenias 6 \\ ${ }^{1}$ INRA, Station de Recherches sur la Nutrition des Herbivores, UR Valeur Alimentaire, \\ 63122 Saint-Genès-Champanelle; \\ 2 Station de Haute-Belgique, rue de Serpont, 100-6800 Libramont, Belgium; \\ 3 INRA, Station d'Amélioration des Plantes Fourragères, 86600 Lusignan; \\ ${ }_{4}$ ITCF-Institut Technique des Céréales et des Fourrages, 91720 Boigneville; \\ 5 ITCF-Institut Technique des Céréales et des Fourrages, 44370 Varades; \\ ${ }^{6}$ Limagrain, Station Expérimentale de Mons, 63203 Riom, France
}

(Received 19 July 1992; accepted 25 January 1993)

\begin{abstract}
Summary - The composition and digestibility by sheep of 15 commercial maize varieties and 1 brown mid-rib experimental hybrid was measured over 2 yr in 7 locations, according to earliness as fresh-cut forage from the milky stage of the grain to the glazed stage. This study determined the effect of the main factors causing variations in plant composition and digestibility. Under satisfactory growing conditions, the digestibility of a given maize hybrid increases significantly with growth stage, whereas it changes very little under poor conditions (low temperatures, drought, etc). For a given dry matter content, genotype effects were significant in only 2 locations and were of similar importance to those of environment (location and year) on a given genotype. As for other forage crops, maize digestibility is closely linked $(R=0.98)$ to its undigestible cell wall content. In contrast, the digestibility of maize cell walls is not only independent of their content in the plant but also lower than that of other forage crops ( -10 points for the same ADL/ADF ratio).
\end{abstract}

maize forage / fresh / composition / digestibility / sheep

Résumé - Composition et valeur alimentaire de la plante entière verte de maïs pour les ovins. I. Facteurs de variation. Dans le cadre d'une étude concertée (INRA, ITCF, AGPM, sélectionneurs de mais), 15 hybrides commerciaux et un hybride expérimental Brown mid-rib (bm3) ont été répartis selon leur précocité (tableau I) dans 7 lieux (Clermont-Ferrand, Dijon, La Jaillère, Le Pin-au-Haras, Lusignan, Rennes et Toulouse) et, dans 5 de ces lieux, durant 2 années consécutives (tableau (I). La composition (morphologique et chimique), la solubilité enzymatique (selon 3 méthodes) et enfin, la digestibilité in vivo (4 à 6 moutons alimentés en quantité limitée), ont été mesurées sur la plante verte durant 4 à 7 sem du stade laiteux au stade vitreux du grain, soit sur un total de 48 cultures de maiss. La valeur moyenne et le coefficient de variation de ces mesures figurent dans le tableau IV. Cette étude a permis de préciser linfluence du stade de récolte sur la composition de la plante de maïs et, plus particulièrement, sur celle de ses parois : leurs teneurs en hémicel- 
luloses s'accroît au détriment de celles en cellulose et lignine (figs 4 et 5) quand la plante vieillit. $\dot{A}$ même stade de récolte, il existe des differences significatives de composition dues à l'hybride et aux conditions de milieu (lieu, année), mais il existe de nombreuses interactions entre facteurs (cf Annexes 2, 3 et 4). Les effets les plus constants d'un essai à l'autre sont ceux de l'année (MAT), du lieu (cendres) et de l'hybride (lignine). La digestibilité de la matière organique des hybrides du commerce a été en moyenne de $71,7 \%$ et a varié de 67 à $78 \%$, ce qui est comparable aux résultats obtenus 15 ans auparavant dans notre laboratoire sur d'autres hybrides. Contrairement aux études antérieures, la digestibilité a augmenté significativement avec la teneur en matière sèche de la plante (jusqu'à une teneur de 35\%) mais de manière variable selon les années. Cet aspect est discuté. À même teneur en matière sèche, les différences de digestibilité entre hybrides n'ont été significatives que dans 2 lieux (Clermont-Ferrand et Lusignan). Elles sont restées alors inférieures à 5 points et n'ont pas été toujours retrouvées d'un lieu à un autre. D'après des comparaisons plus partielles permises par le dispositif expérimental, l'influence du lieu et de l'année semble au moins équivalente à celle de l'hybride (Annexes 3 et 4). La digestibilité réelle des constituants cytoplasmiques étant voisine de $100 \%$, la digestibilité de la plante entière est, comme celle des autres plantes fourragères, liée très étroitement à sa teneur en parois indigestibles $(R=0,98$; fig 8 ). En revanche, les parois du maïs se différencient sensiblement de celles des autres plantes: leur digestibilité est liée de manière plus lâche à leur degré de lignification (rapport ADLADF) et, pour un mêrme degré de lignification, est nettement plus faible (en moyenne de 10 points pour les hybrides du commerce, fig 11). Enfin, la digestibilité des parois du maïs est indépendante de leur teneur dans la plante. Ces éléments, qui sont discutés, sont invoqués pour expliquer la valeur prédictive relativement médiocre de la solubilité enzymatique, et surtout de la composition chimique, pour prévoir la digestibilité du maïs.

maïs fourrage frais / composition / digestibilité / ovin

\section{INTRODUCTION}

The last studies by INRA concerning the factors causing variation in the composition and food value of fresh or preserved (silage or dehydrated) maize were carried out $>15$ yr ago (eg Demarquilly and Andrieu, 1974; Andrieu, 1975). These studies mainly conceed grain maize varieties. Since this date, commercial varieties with greater grain productivity or specially adapted to silage-making have been introduced. In addition, new methods (enzymatic, spectrometric) of predicting quality attributes have been developed and it appeared important to compare their accuracy with those of chemical methods of predicting in vivo digestibility of maize. For these reasons, a joint study by INRA, ITCF, AGPM and breeders ("Club Digestibilité") was undertaken on forage maize nutritive value. The main objectives were:
- to determine under French conditions, factors causing variation in composition and digestibility of fresh plants of 15 registered hybrids and 1 experimental hybrid (present article);

- to compare different methods for predicting in vivo digestibility (morphological and chemical composition, enzymatic digestibility, near infra-red spectrometry used in animal husbandry (Dardenne et al, 1992) or in plant breeding (Barrière et al, 1991);

- to constitute a bank of reference samples usable for testing methods of prediction.

\section{MATERIALS AND METHODS}

Although the main objective was to study the in vivo digestibility and energy value of maize silage, it was decided to use fresh maize for 2 reasons: 
- firstly, digestibility of silage at $>25 \%$ dry matter (DM) is almost identical to that of the fresh plant (Andrieu and Demarquilly, 1974; Andrieu, 1985);

- secondly, trials with silage are more difficult to carry out satisfactorily (use of silos, necessity for correction of results according to losses of volatile substances during oven-drying of samples).

Over $2 \mathrm{yr}, 15$ commercial varieties which were as different as possible and $t$ experimental hybrid, bm3, were selected (table I) by a working group and coded 1 to 17 . The 16 hybrids were grown in 7 trial locations (ClermontFerrand, Dijon, La Jaillère, Le Pin-au-Haras, Lusignan, Rennes and Toulouse) where it was possible to measure in vivo digestibility on sheep (table II). As the variability due to environmental conditions (location, year) had been found (Andrieu, 1976) to be as or if not more important than that between genotypes, several hybrids (numbers 1, 2, 4, 5 and 10) were studied over $2 \mathrm{yr}$ in several locations. Overall, 48 maize crops were studied.

The general conditions of the experimental design over the $2 \mathrm{yr}$ are given in table III. It may be noted that sowing was deliberately late (June 5-6th) in Rennes in order to reproduce the case of maize crops sown in Brittany after Italian ryegrass silage crops.

Sowing conditions were good except at Le Pin-au-Haras, where, because of problems with a drill, plant populations were lower than elsewhere and also more irregular. Fertilization was according to soil agronomic characteristics and thus varied between locations (table III). It in-
Table I. Hybrids studied.

French catalogue

$\begin{array}{ll}\text { Very early } & \text { Alsa } \\ & \text { Anjou 09 } \\ & \text { Keo DK } 182\end{array}$

Early

Artus

Gracia

Lixis LG 22.21

Anjou 29

Arcade

Half-early

Dea

Mammouth

Monarque 282

Half-late Eva

Late Ogalo

Sabrina

European catalogue Bastion

INRA Lusignan HTV bm3

Table II. Hybrid trial locations (coded 1 to 17).

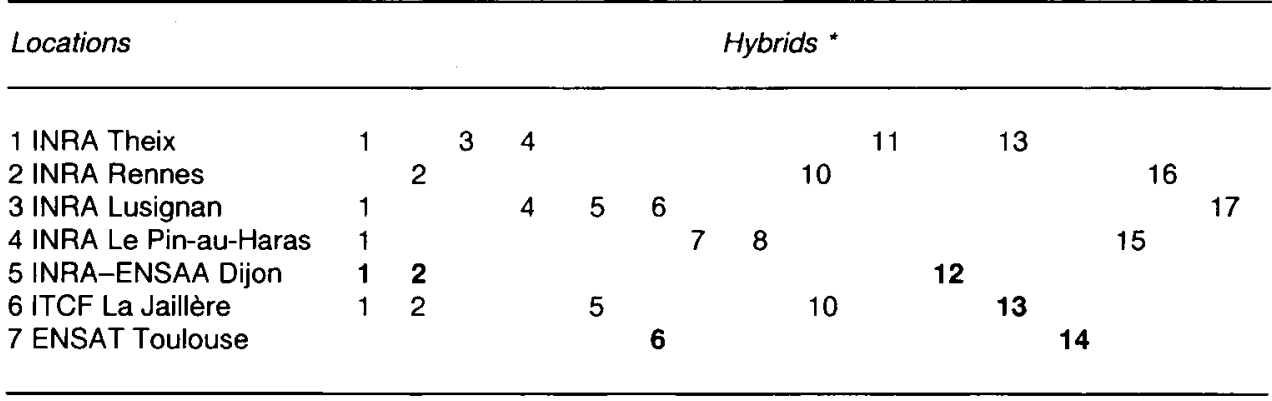

\footnotetext{
* The hybrids codes in bold type indicate that they were studied in only 1 year.
}

cluded some organic manure (liquid or solid manure) at Le Pin, Rennes, and la Jaillière. Growing conditions (temperature, rainfall) were generally good. 1987 was characterised by a rather cold spring and a particularly hot and dry September and October (table III). In 1988, temperatures were generally lower than in 1987 during the phase of grain maturation in September. 


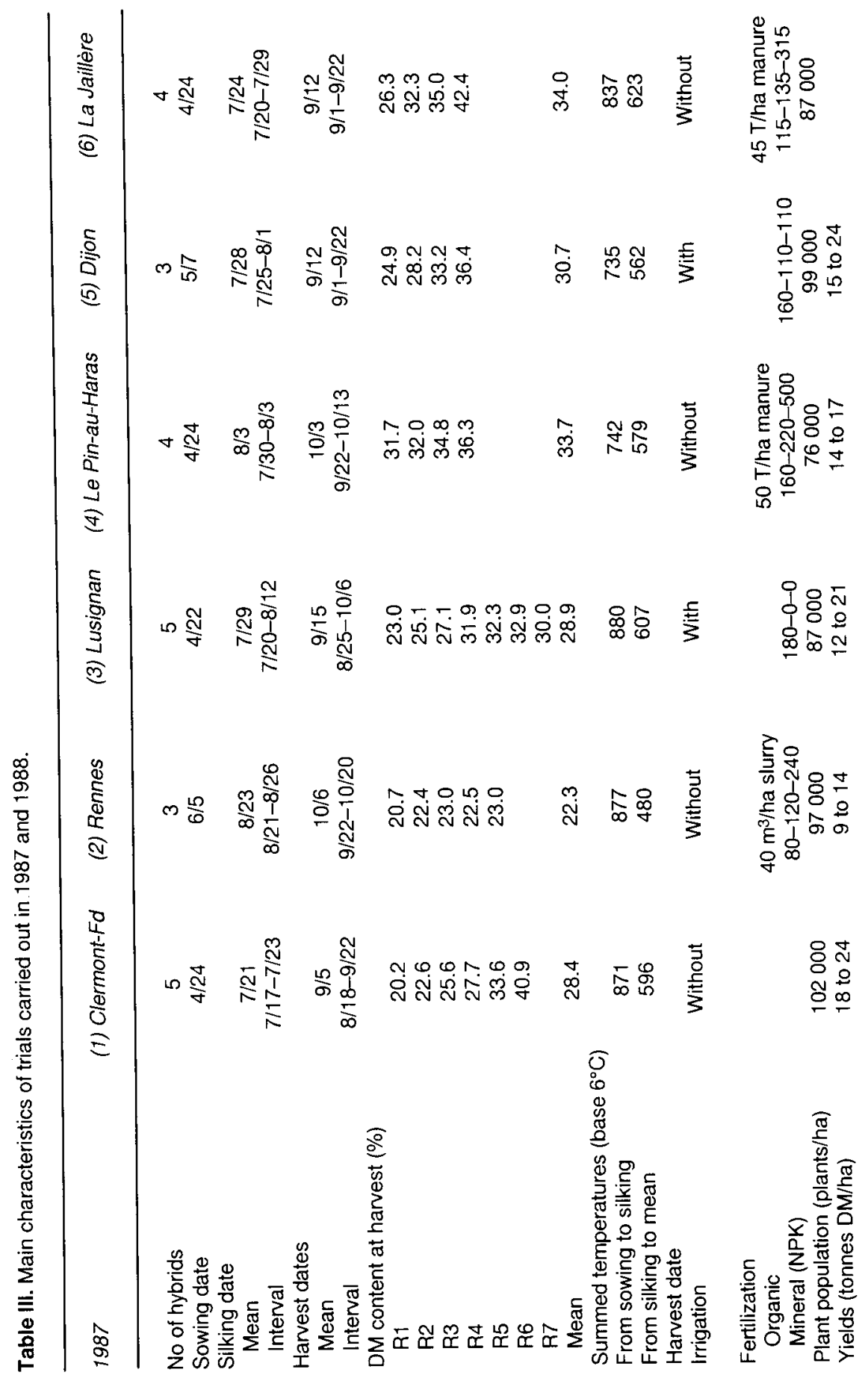




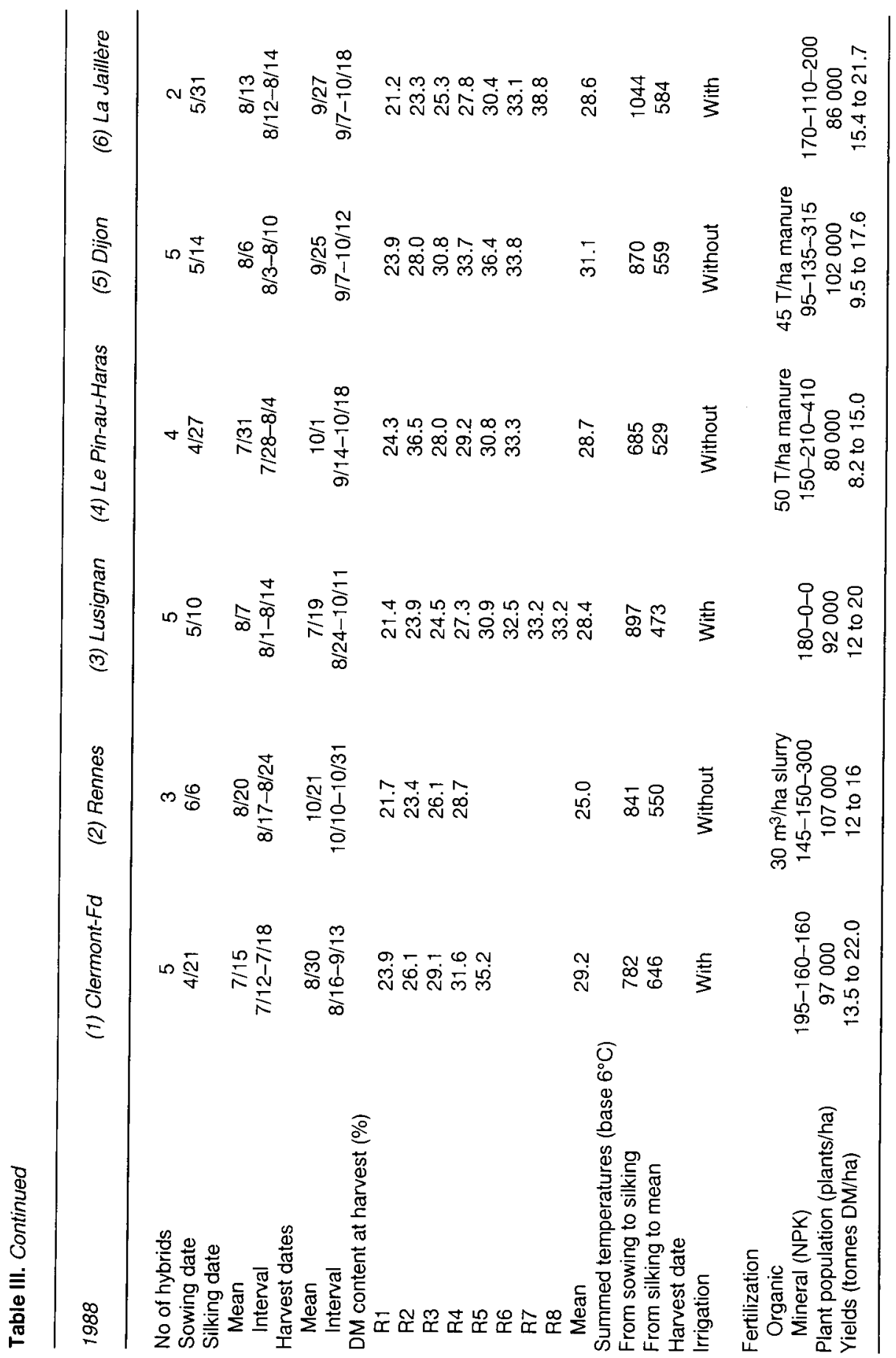


The main crop damage sustained was partial lodging of maize at Rennes in 1988 due to a storm just before the beginning of measurements and rapid drying of the 1987 La Jaillère crop as a result of a drought associated with a Fusarium attack.

\section{Measurements on plants}

For each hybrid, the date of silking $(50 \%$ of plants with silks visible on the upper ear) was determined on $2 \times 5-m$ rows. During each period of digestibility measurements (see below), the plants present in 1 or $25-\mathrm{m}$ rows were counted, harvested and divided into 2 fractions (whole ear and stems + leaves), then weighed fresh. In order to determine the DM content and the respective proportions in DM of stems + leaves, ear and grain, a subsample of these constituents was oven-dried (48 to $72 \mathrm{~h}$ at $80^{\circ} \mathrm{C}$ ). The mean yield/ha estimated from these samples was 15 tonnes $D M$, with a wide range of variation (7 to 25 tonnes; table III). This was due not only to the stage of grain maturation at sampling and to environmental conditions, but also to the precision of sampling methods and heterogeneity of plant populations (Le Pin-auHaras). Similarly, the rate of increase in dry weight was very variable, and much lower at Rennes, le Pin-au-Haras and La Jaillère (in 1987) than in the other locations.

\section{Measurements on sheep}

The digestibilities of whole plants of each plot were measured on 6 castrated wethers in individual metabolic cages with feed in limited quantity $(42 \pm 3 \mathrm{~g} \mathrm{DM} / \mathrm{kg} \mathrm{W0.75}$ in 2 meals per day) to avoid selection and limit digestive interactions. So that the protein and mineral contents were not limiting factors for maize digestion in the rumen (Andrieu and Demarquilly, 1974), the animals received at the trough a nitrogen (urea) and mineral (major and trace elements) supplement. This supplement was fed in order to provide $15 \mathrm{~g}$ urea/kg whole maize plant DM. After a 10-d period of adaptation, the main measurements were carried out continuously for each crop for 4 to 7 periods, from the milky stage to the glazed stage of grain: each period lasted for $6 \mathrm{~d}$ ( $5 \mathrm{~d}$ at Lusignan), separated from the following period by $1 \mathrm{~d}$ ( $2 \mathrm{~d}$ at Lusignan). A representative sample of the forage provided (without the urea-mineral supplement) during each period was taken from the 12 sub-samples in order to determine the DM content of each of the 2 daily meals (dried at $80^{\circ} \mathrm{C}$ for $48 \mathrm{~h}$ ). A representative sample of the faeces excreted by each sheep was taken from the daily collection of faeces. In spite of the limited diet, some animals refused feed at certain periods, and were eliminated from calculations when their DM digestibility differed by $>5$ points from the mean value for the considered period. The number of sheep restrained per period ranged from 3 to 6 . All the representative samples of maize fed to the animals and the corresponding faeces were ground in the same mill (Gondart, 1-mm mesh).

Under these experimental conditions, the precision of DM digestibility measurements (SD of error) was 2.34 and 1.89 points respectively before and after elimination of individual results differing by $>5$ points from the mean value for each measurement period.

\section{Analytical methods}

For the 234 representative samples of maize and the corresponding faeces, the following characters were determined:

- usual chemical composition: ash, crude protein $(N \times 6.25)$, Weende crude fibre;

- starch content by the Ewers (1910) method, water soluble carbohydrate (Somogyi, 1952), neutral detergent fibre (NDF), acid detergent fibre $(A D F)$, acid detergent lignin $(A D L)$ contents by method proposed by Van Soest (1967), and adapted by Giger et al (1979). The $A D L$ was corrected by the ash content. The hemicellulose (NDF-ADF) and cellulose ( $A D F-A D L)$ contents were obtained by subtraction;

- enzymatic solubility by 3 methods (Aufrere and Michelet-Doreau, 1983; Lila et al, 1986; Limagrain, 1985). The methodologies are defined in Appendix 1.

In addition, on a more restricted number of samples (those from Clermont-Ferrand and Lusignan), the following additional measurements were made:

- plant starch content, determined by the enzymatic method of Thivend et al (1965), in order to make a comparison with the Ewers' method ( $n=$ 53); 
- NDF, $A D F$ and $A D L$ contents of the faeces, in order to determine the digestibility of these constituents $(n=99)$;

- gross energy contents (adiabatic bomb calorimeter) of plants $(n=59)$ and of certain faeces $(n=37)$, in order to calculate relations allowing prediction of gross and digestible energy.

\section{Statistical analysis}

The analysis of variance and covariance (the covariate used was plant DM) were made using the programme of Seebeck (1973) with calculation of factor $x$ factor or factor $x$ covariate (regression slope) interactions on the following equilibrated factorial plants:

\section{Three-factor analysis}

The following hybrids were studied in 2 consecutive yr (1987 and 1988): 1 and 4 at Clermont-Ferrand and Lusignan; 1 and 5 at Lusignan and La Jaillière; 2 and 10 at Rennes and $L a$ Jaillère.

Appendix 1. Methodologies for the 3 enzymatic methods used.
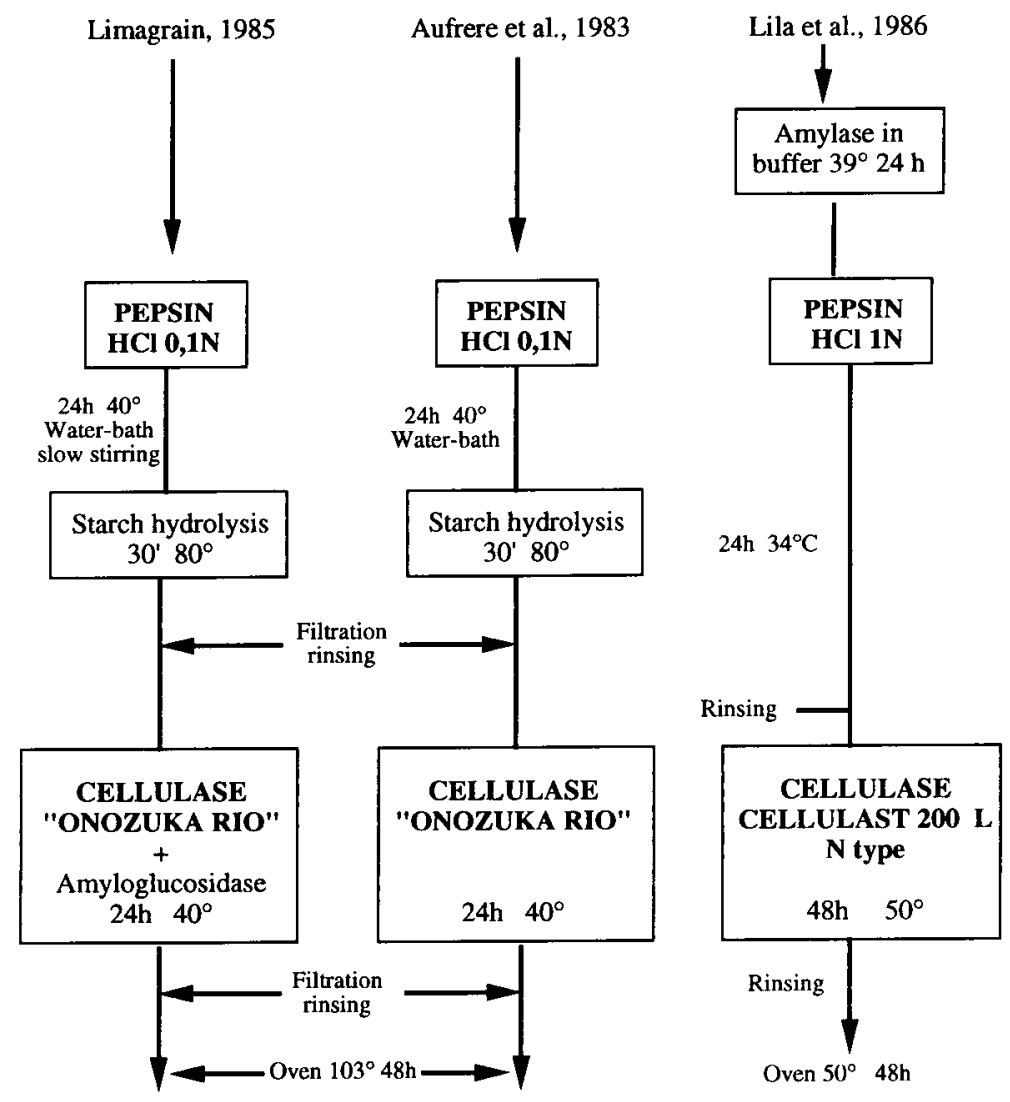


\section{Two-factor analysis}

The following hybrids were studied in 2 consecutive yr (1987 and 1988): 1, 3, 4, 11, 13 at Clermont-Ferrand; 2, 10, 16 at Rennes; 1, 4, 5, 6, 17 (bm3) at Lusignan; $1,7,8,15$ at Le Pin-auHaras; $1,2,5,10$ at La Jaillière; 1 at Theix, Lusignan, Le Pin and La Jaillière.

\section{Single-factor analysis}

The following hybrids were studied in 2 consecutive years: $1,2,12$ at Dijon in 1987; 6, 14 at Toulouse in 1988.

\section{RESULTS}

\section{Gross energy contents and digestibility}

The average gross energy content was $4660 \pm 33 \mathrm{Kcal}$ per kg organic matter (OM) for the 59 samples studied. For a given variety, the gross energy content dropped slightly with age (expressed as d after silking); it is thus linked to some extent to chemical and morphological composition. The best prediction criteria appear to be DM, protein and lignin contents. Since DM content depends partly on climatic conditions, it is proposed to use, as for other forages (Demarquilly et al, 1978), the following relation between gross energy ( $G E$ in $\mathrm{Kcal} / \mathrm{kg} O M$ ) and crude protein content ( $C P$ in $\mathrm{g} / \mathrm{kg} O M$ ):

$\begin{aligned} G E & =4487+2.019 C P \pm 25 ; R=0.578 \\ N & =59\end{aligned}$

$$
N=59
$$

However, this equation overestimates by $\approx 70 \mathrm{Kcal}$ the hybrids carrying the gene $\mathrm{bm} 3$ with reduced lignin content. For these hybrids, it is preferable to use an equation also including the lignin content $(A D L$ in $\mathrm{g} /$ kg $O M$ :

$$
\begin{aligned}
G E & =4548+0.37 C P+3.29 A D L \pm 26 ; \\
R & =0.621 ; N=53
\end{aligned}
$$

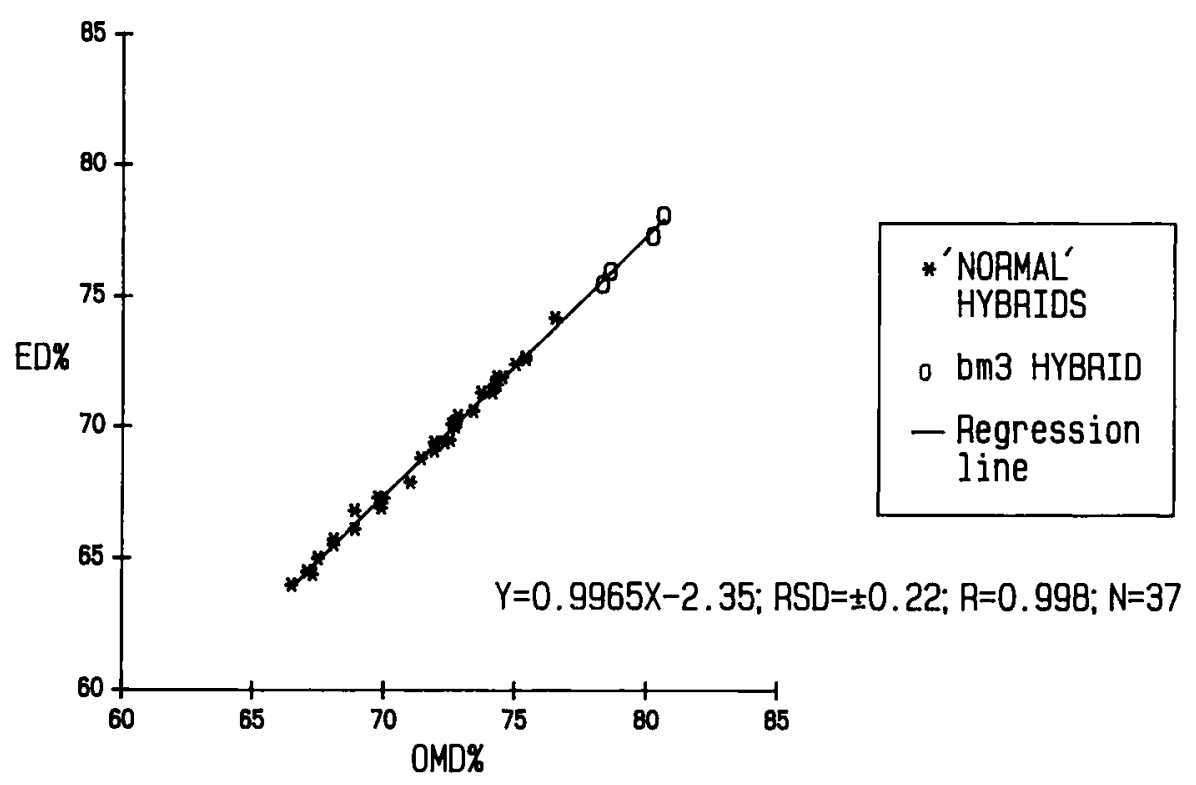

Fig 1. Relationship between energy digestibility $(E D)$ and organic matter digestibility $(O M D)$ of wholeplant maize fed fresh to sheep. 
Energy digestibility ( $E D$ in \%) with a mean of $69.9 \pm 3.6 \%$ for the 37 measurements made is closely related to organic matter digestibility (OMD in \%) (fig 1):

$$
\begin{aligned}
E D & =0.9965 O M D-2.35 \pm 0.22 ; \\
R & =0.998 ; N=37
\end{aligned}
$$

These results were used to calculated the net energy values (following 1988 INRA standards) of the maize hybrids studied in part II (Dardenne et al, 1993).

\section{Influence of growth stage}

This study showed, sometimes with improved precision, the general rules concerning change in plant composition according to age. Age, expressed by d after silking, varied from 20 to 83 (with a mean of $49 \mathrm{~d}$ ). For a given hybrid or for the series of hybrids, DM content increased with age (fig 2), mainly because of the relative increase in grain content $(R=0.776$; fig 3$)$. The development of grain results from the formation of starch (STA in $\mathrm{g} / \mathrm{kg}$ DM ac- cording to the Ewers method), from watersoluble carbohydrates (WSC in $\mathrm{g} / \mathrm{kg}$ DM) synthesized after flowering or that were stored earlier (mainly in the stem) so that, as other authors have indicated (Demarquilly, 1969), a close inverse relation exists between these 2 constituents:

$$
\begin{aligned}
S T A & =450-1.7986 W S C \pm 40 \\
R & =0.873 ; N=234
\end{aligned}
$$

During the same period, the contents of other constituents drop (fig 4) noticeably (crude fibre, $A D F$ ) or slightly (ash, crude protein, NDF, $A D L$ ). The composition of cell walls (as a percentage of NDF) varied little according to stage (fig 5): the hemicellulose content (mean $51.7 \pm 2.9 \%$ ) increased at the expense of the cellulose content (mean $43.3 \pm 2.4 \%$ ), whereas the lignin content (mean $5.1 \pm 0.8 \%$ ) showed a tendency to decrease.

There exists quite close relations between certains morphological and chemical constituents. The following are the most significant (for abbreviations and units, see table IVa):

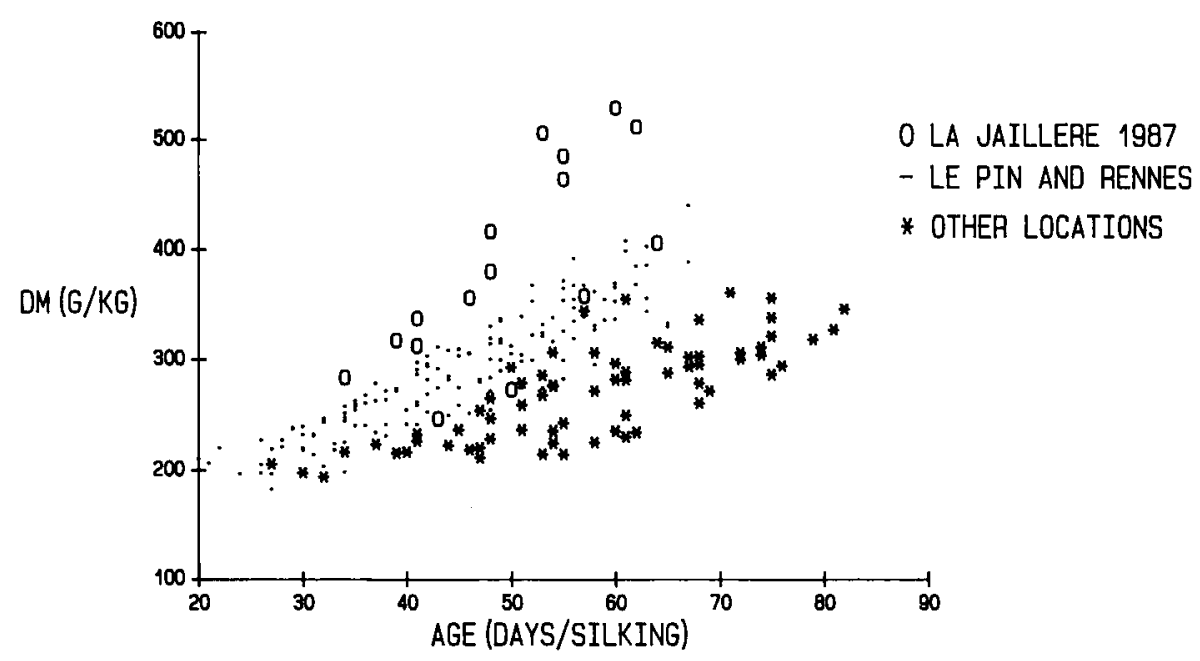

Fig 2. Relationship between DM content of maize plant and its age. 


$$
\begin{aligned}
G R A & =754-0.008823 C F^{2} \pm 73 \\
R & =0.761 ; N=234(\text { fig } 6) \\
G R A & =26.5+1.7159 S T A-0.00098 S T A^{2} \\
& \pm 40 ; R=0.935 ; N=234(\text { fig } 6) \\
S T A & =838-2.8921 C F \pm 47 ; R=0.816 ; \\
N & =234 \\
S T A & =862-2.7365 A D F \pm 43 \\
R & =0.847 ; N=234 \\
A D F & =10.7+1.0480 C F \pm 7.4 ; \\
R & =0.957 ; N=234
\end{aligned}
$$

More generally, the ratio of total cytoplasmic carbohydrates (starch + soluble carbohydrates) and cell walls (NDF) increases from 0.4 to 0.9 during grain development.

For the 53 comparisons, the starch content measured by the methods of Thivend et al (1965) ( $Y$ in $\mathrm{g} / \mathrm{kg} \mathrm{DM}$ ) was, on average, $14.7 \mathrm{~g}$ higher than that obtained with Ewers' method. As the following equation shows, the difference between the 2 methods is reduced when the starch content is high, that is, at later harvest dates:

$$
\begin{aligned}
& Y=37.05+0.9131 X \pm 14.4 ; R=0.987 \\
& N=53
\end{aligned}
$$

In general, age is a poor predictor of plant composition since the latter depends mainly on grain development and thus on temperature. For a given age, the sums of temperatures after flowering (base $6^{\circ} \mathrm{C}$ ) varied significantly between locations. This is the reason why DM content and sum of temperatures which are quite closely correlated in normal growing conditions provide a better prediction of plant composition. Of the 2 growth stage criteria, neither of which is entirely satisfactory, DM content appears preferable due to its nutritional significance and to its frequent use in publications on this subject.

\section{Influence of other factors}

For a given location and a given DM content, there are significant year and genotype effects on chemical composition (Appendix 2,3 ).

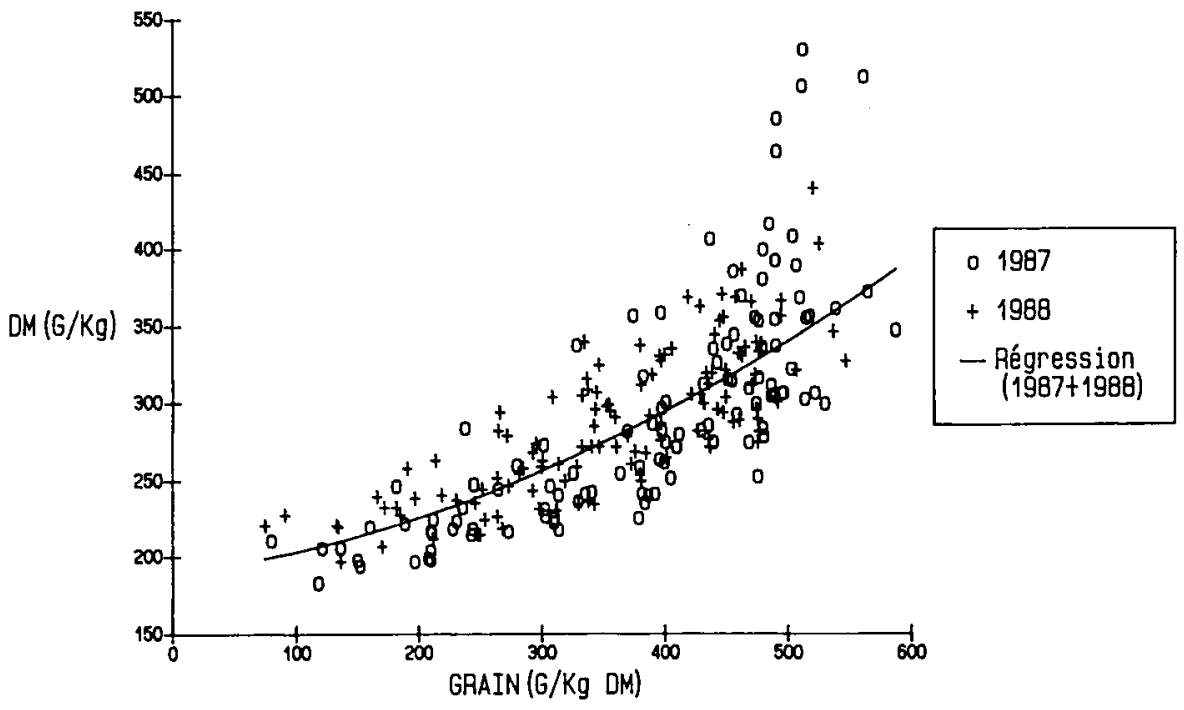

Fig 3. Relationship between DM and grain content of maize plant. 
1987

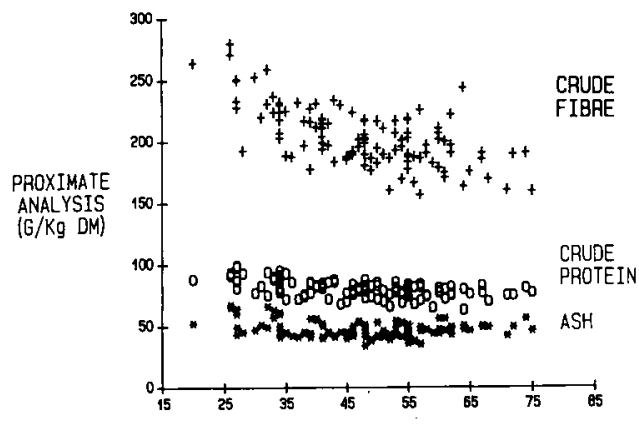

1988

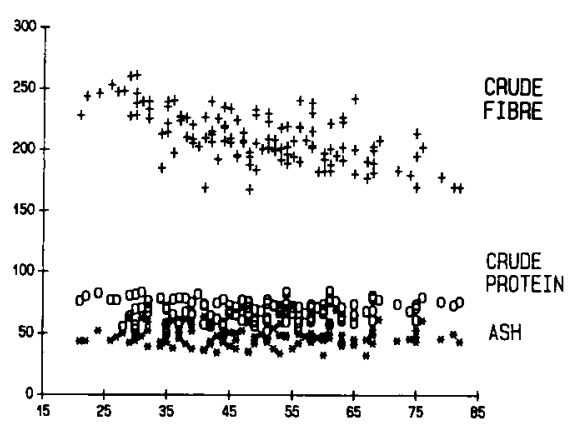

VAN SOEST
CONSTITUENTS
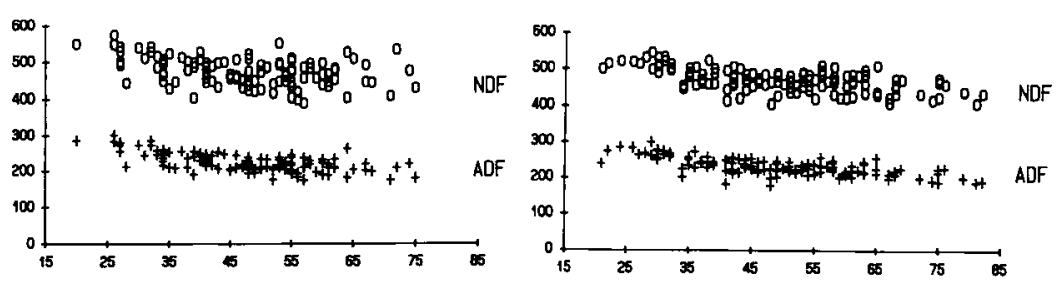

(G/Kg DM)
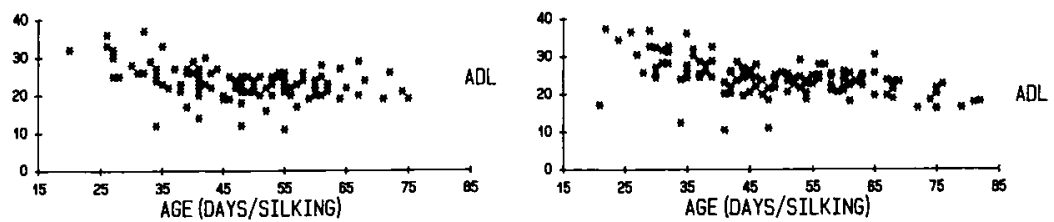

Fig 4. Relationship between chemical composition of maize plant and its age during $2 \mathrm{yr}$.

However, the appearance, in most locations, of interactions between year and hybrid (eg at Lusignan) or between year and DM content (Rennes and La Jaillère) makes it difficult to analyse these effects. Of the chemical composition parameters, protein content is the most affected by year; it was always lower in 1988 (mean of $69 \mathrm{~g}$ ) than in 1987 (mean $80 \mathrm{~g}$ ) except at Rennes, where greater fertilisation in 1988 may have masked the effect (table III).
Genotypic effects, when significant, mainly concern crude protein and cell-wall contents, but have very little effect on WSC. These effects were particularly noticeable at Clermont-Ferrand, where, in the absence of any significant interactions, it was possible to distinguish hybrid 13 from hybrid 3 (table $V$ ) by its higher grain and starch contents and lower cell-wall contents (crude fibre and $A D L$ ). If in order to analyse effects at the usual stage for si- 
Table IV. Composition and nutritive value of maize hybrids studied: means, range of variation, coefficient of variation (CV) observed for the 234 samples and the bm3 hybrid.

\begin{tabular}{|c|c|c|c|c|}
\hline A. The 234 samples $(\mathbb{N}=234)$ & Abbreviation & Means & Variation range & $C V(\%)$ \\
\hline 1 Age at harvest ( $d$ after silking) & $A G E$ & 49 & $20-82$ & 27 \\
\hline 2 Summed temperatures at harvest a & ST6 & 558 & $270-913$ & 23 \\
\hline \multicolumn{5}{|l|}{ Morphological composition (g/kg DM) } \\
\hline 3 Grain & GRA & 370 & $75-590$ & 31 \\
\hline 4 Ear (with husks) & $E A R$ & 510 & $270-680$ & 19 \\
\hline \multicolumn{5}{|l|}{ Chemical composition b } \\
\hline 5 Dry matter & $D M$ & 291 & $183-531$ & 21 \\
\hline 6 Ash & $A S H$ & 48 & $33-80$ & 17 \\
\hline 7 Crude protein & $C P$ & 74 & $50-99$ & 12 \\
\hline 8 Crude fibre & $C F$ & 208 & $157-280$ & 11 \\
\hline 9 NDF & NDF & 473 & $389-575$ & 7 \\
\hline $10 A D F$ & $A D F$ & 229 & $174-302$ & 11 \\
\hline $11 A D L$ & $A D L$ & 24 & $11-37$ & 21 \\
\hline 12 Starch & STA & 236 & $29-404$ & 34 \\
\hline 13 Water-soluble carbohydrates & WSC & 119 & $36-226$ & 34 \\
\hline \multicolumn{5}{|l|}{ Enzymatic solubility (\% DM) } \\
\hline 14 Aufrère method & AUF & 71.0 & $61.2-83.1$ & 4 \\
\hline 15 Limagrain method & LGS & 78.8 & $70.3-88.7$ & 4 \\
\hline 16 Lila method & $A P C$ & 79.6 & $70.6-90.3$ & 4 \\
\hline \multicolumn{5}{|l|}{ In vivo digestibility (\%) } \\
\hline 17 Organic matter & $O M D$ & 71.9 & $66.5-80.6$ & 4 \\
\hline 18 Crude fibre & $C F D$ & 56.7 & $41.9-76.3$ & 10 \\
\hline
\end{tabular}

B. The bm 3 hybrid $(\mathrm{N}=8)$

\begin{tabular}{|c|c|c|c|c|}
\hline $\begin{array}{l}1 \text { Age at harvest (d after silking) } \\
2 \text { Summed temperatures at harvest a }\end{array}$ & AGE & 40 & $21-55$ & 26 \\
\hline \multicolumn{2}{|l|}{ Morphological composition ( $\mathrm{g} / \mathrm{kg} \mathrm{DM}$ ) } & 492 & $270-706$ & 27 \\
\hline 3 Grain & GRA & 348 & $170-490$ & 27 \\
\hline 4 Ear (with husks) & $E A R$ & 515 & $374-604$ & 15 \\
\hline \multicolumn{5}{|l|}{ Chemical composition b } \\
\hline 5 Dry matter & $D M$ & 279 & $207-355$ & 18 \\
\hline 6 Ash & $A S H$ & 44 & $35-52$ & 13 \\
\hline 7 Crude protein & $C P$ & 80 & $73-86$ & 6 \\
\hline 8 Crude fibre & $C F$ & 190 & $+68-228$ & 11 \\
\hline 9 NDF & NDF & 449 & $406-501$ & 7 \\
\hline $10 A D F$ & $A D F$ & 204 & $179-239$ & 10 \\
\hline $11 A D L$ & $A D L$ & 13 & $10-17$ & 17 \\
\hline 12 Starch & STA & 206 & $35-301$ & 40 \\
\hline 13 Water-soluble carbohydrates & WSC & 148 & $121-170$ & 12 \\
\hline \multicolumn{5}{|l|}{ Enzymatic solubility (\% DM) } \\
\hline 14 Aufrère method & AUF & 79.7 & $77.6-83.1$ & 3 \\
\hline 15 Limgrain method & LGS & 87.7 & $85.5-88.7$ & 1 \\
\hline 16 Lila method & $A P C$ & 88.6 & $86.4-90.3$ & 2 \\
\hline \multicolumn{5}{|l|}{ In vivo digestibility (\%) } \\
\hline 17 Organic matter & $O M D$ & 78.5 & $75.1-80.6$ & 4 \\
\hline 18 Crude fibre & $C F D$ & 70.0 & $64.0-76.3$ & 6 \\
\hline
\end{tabular}

a Calculated from silking with a base temperature of $6^{\circ} \mathrm{C}$; ${ }^{b}$ in $\mathrm{g} / \mathrm{kg} \mathrm{DM}$ except for DM content $(\mathrm{g} / \mathrm{gross} \mathrm{kg})$. 


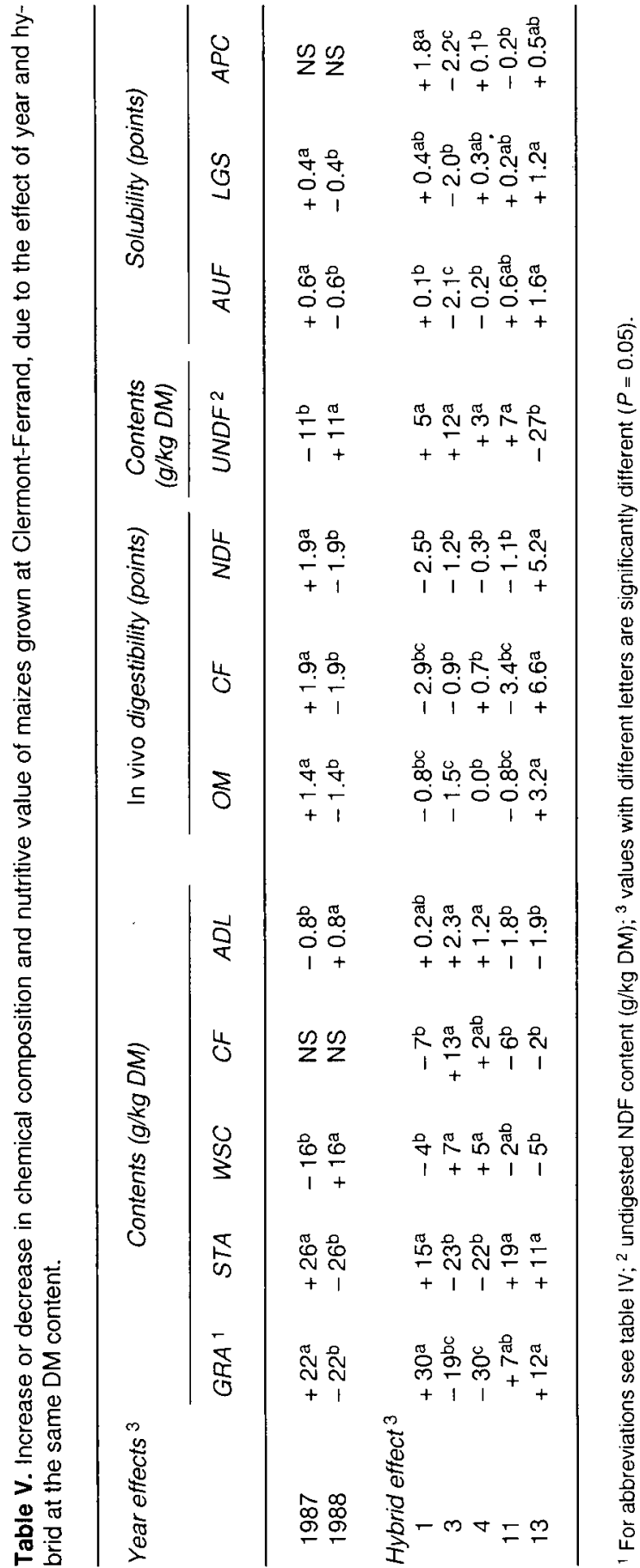




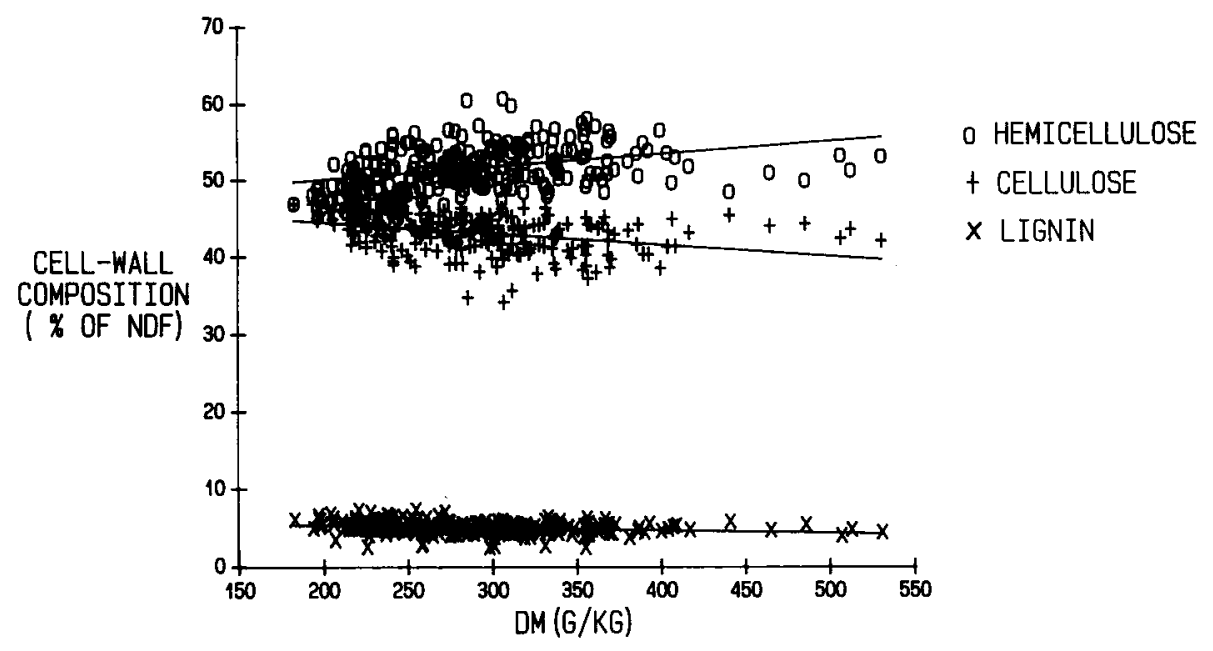

Fig 5. Relationship between cell-wall composition and DM content of maize plant after silking.

lage production, only the samples with a DM content $>27.5 \%$ are taken into account, the growth stage $x$ genotype interactions remain significant.

Analyses of location effects were limited by the experimental design (Appendix 3, 4). Overall, this factor appears as important as year and genotype. Ash content is one of the constituents most affected by trial location.

\section{In vivo digestibility}

Mean organic matter digestibility (OMD) was $71.9 \%$, varying from 67 to $81 \%$. Discounting results obtained with the hybrid $\mathrm{bm} 3$, the mean value $(71.7 \%)$ and the range of variation (67 to $78 \%$ ) were comparable with earlier results (Demarquilly and Andrieu, 1973).

Generally, digestibility showed little variation according to growth stage at harvest, in particular measured by DM content $(R=$ $+0.182^{\star *}$ [significant at $P=0,01$ ] $N=$ 234): from a mean of $70.8 \%$ at $20 \% \mathrm{DM}$, there was an increase to a maximum of $72.5 \%$ at $36 \%$ DM and thereafter a slow reduction. This variation with stage was, however, different according to location (Appendix 3, fig 7): it was considerable and significant at Clermont-Ferrand, Lusignan, Dijon and Toulouse, and negligible at Rennes, Le Pin and La Jaillière.

For all locations at a given DM content there was a significant year effect (Appendix 2): in 1987 digestibility was higher than in 1988, in all sites except Rennes, where the opposite trend was observed. In the latter site, for a DM content of $23 \%$, digestibility of the 3 hybrids studied was lower in 1987 than in 1988 by 4 points. The size of the difference between years varied with stage at harvest (interaction) in 4 locations (Clermont-Ferrand, Rennes, Le Pin and La Jaillère).

Genotypic effects were significant $(P<$ $0.01)$ only in 2 locations: Clermont-Ferrand and Lusignan (Appendix 2). Since year $\mathrm{x}$ 
(a)

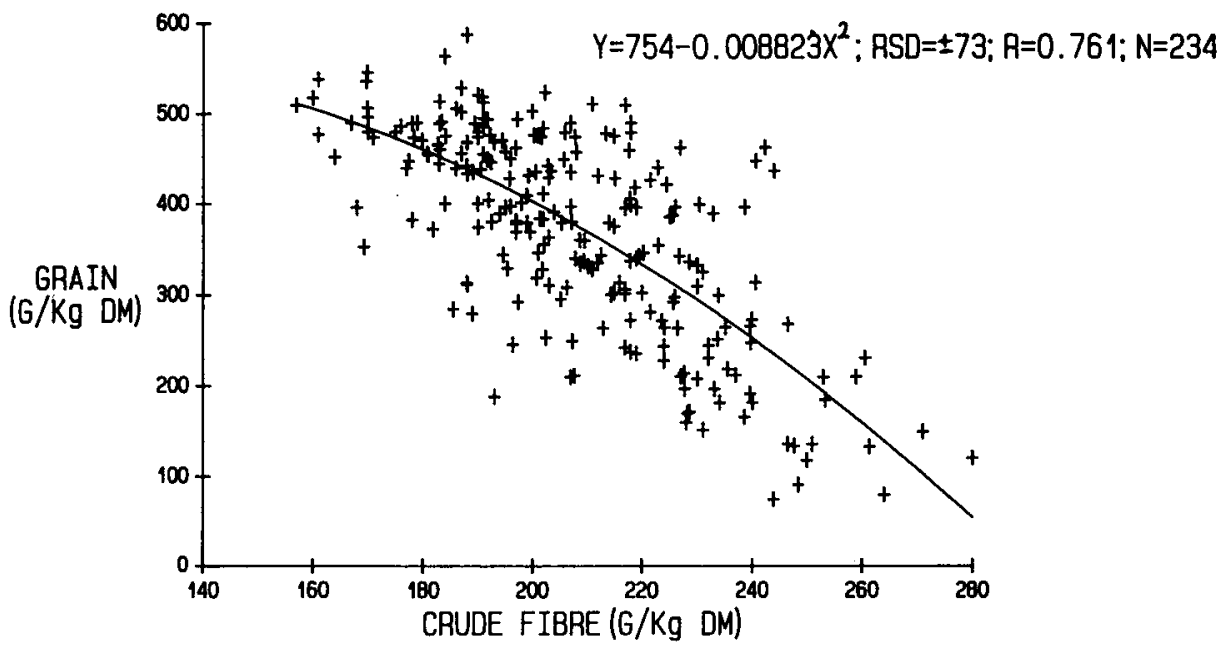

(b)

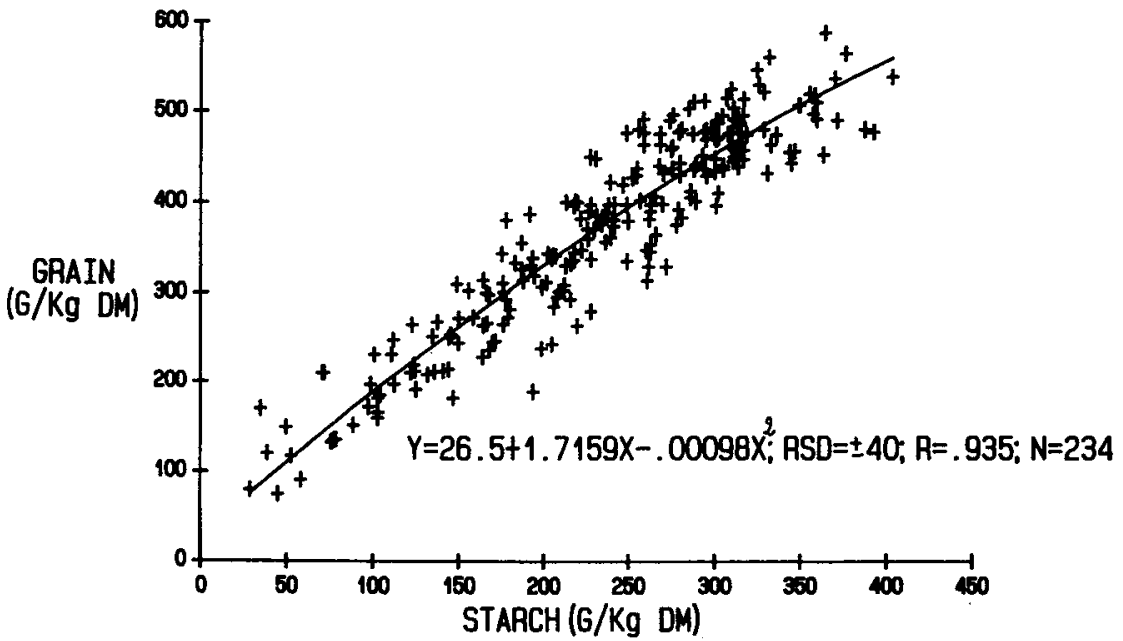

Fig 6. Relationship between grain content of maize plant and its crude fibre (a) or starch content (b). 
hybrid interactions were not significant at Clermont-Ferrand, mean effects independent of stage and year appeared: hybrid 13 was much more digestible $(+4.7$ points) than hybrid 3 (table V). However, it should be noted that compared with 4 other hybrids at La Jaillère in 1988, hybrid 13 was not distinguished by its digestibility. There were also significant genotypic effects at Lusignan, but the year $x$ hybrid interactions made it impossible to determine mean effects, when either all samples or only those with $>27.5 \%$ DM were considered. In contrast, for a given year, in particular 1988, the hybrid bm3 was much more digestible ( +5 points) than the other genotypes.

The other more incomplete comparisons permitted by the experimental plan indicate that location effects are comparable with year effects and more important than those due to genotype (Appendix 2, 3).

Since urea was fed, the digestibility of proteins will not be considered. The digestibility of crude fibre was rather low (a mean of $56.7 \%$ ) and varied between wide limits (42 to $76 \%$ ). Both overall and for single hybrids, it varied independently of stage at harvest (Appendix 2). In contrast, for single locations, it was sometimes related to genotype (Clermont-Ferrand, Lusignan in 1988). From the more complete measurements of digestibility carried out at Clermont-Ferrand and at Lusignan (table VI), the following regressions were calculated between NDF or ADF digestibilities (NDFD or $A D F D$ in percent) and crude fibre (CFD in percent):

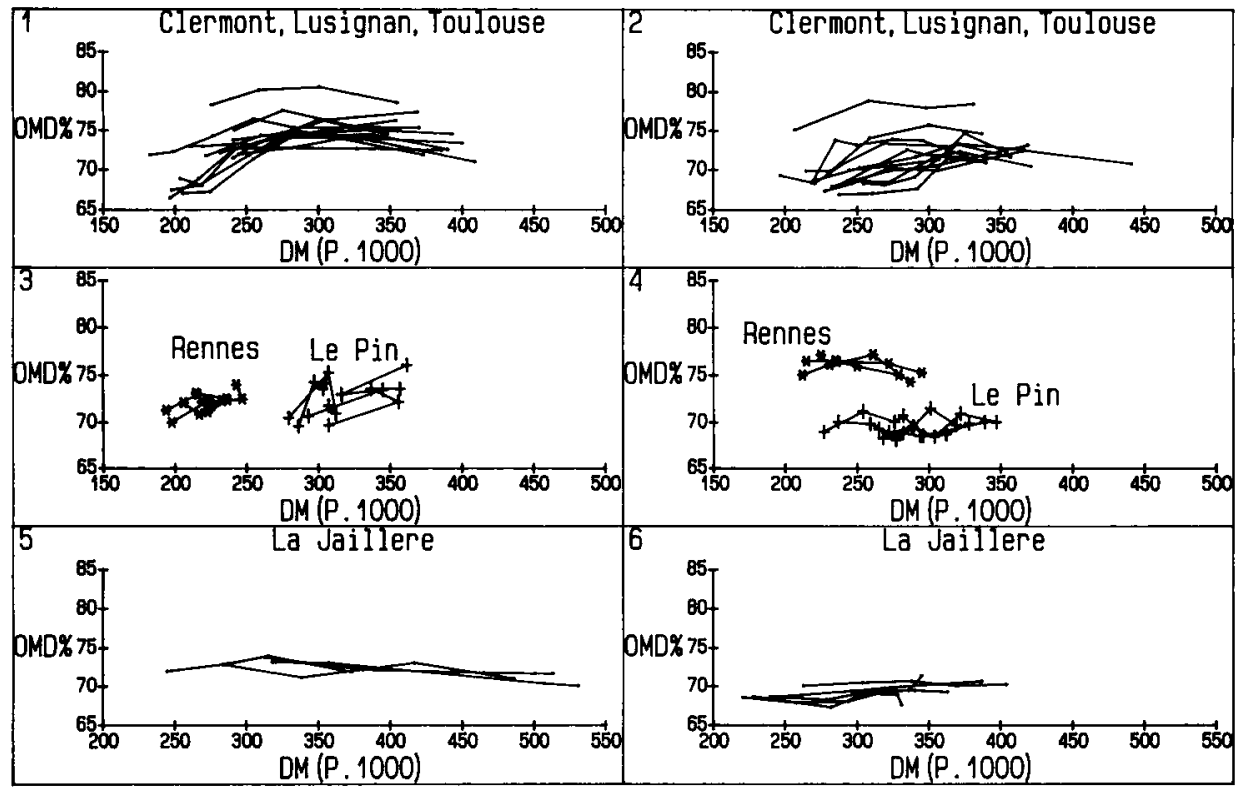

Fig 7. Relationship according to years and locations between $O M D$ of maize plant and its DM content. 
Table VI. Main constituents of DM in maize: contents and in vivo digestibility (crops from ClermontFerrand and Lusignan).

\begin{tabular}{|c|c|c|c|c|}
\hline \multirow[t]{2}{*}{ Parameters } & \multicolumn{2}{|c|}{$\begin{array}{l}\text { Normal hybrids } \\
\qquad(\mathbb{N}=91)\end{array}$} & \multicolumn{2}{|c|}{$\begin{array}{l}\text { Experimental bm3 hybrids } \\
\qquad N=8)\end{array}$} \\
\hline & Mean & $C V \% \mathrm{~b}$ & Mean & $C V \%^{\mathrm{b}}$ \\
\hline \multicolumn{5}{|c|}{ Contents (g/kg DM) } \\
\hline$S^{a}$ & 527 & 7.2 & 551 & 5.7 \\
\hline NDF & 473 & 8.0 & 449 & 7.0 \\
\hline$N D F-A D F$ & 242 & 7.5 & 245 & 4.8 \\
\hline$A D F$ & 231 & 11.9 & 204 & 9.7 \\
\hline$A D F-A D L$ & 206 & 11.6 & 192 & 9.7 \\
\hline$A D L$ & 25 & 17.2 & 13 & 17.4 \\
\hline \multicolumn{5}{|c|}{ In vivo digestibility (\%) } \\
\hline$O M$ & 71.9 & 3.6 & 78.5 & 2.1 \\
\hline$s$ & 80.5 & 2.5 & 81.4 & 2.4 \\
\hline NDF & 56.6 & 7.1 & 69.0 & 4.1 \\
\hline$N D F-A D F$ & 61.0 & 7.1 & 71.2 & 4.4 \\
\hline$A D F$ & 51.7 & 9.7 & 66.5 & 4.1 \\
\hline$A D F-A D L$ & 57.1 & 8.6 & 70.1 & 4.0 \\
\hline
\end{tabular}

a $S=1000-N D F ;{ }^{b}$ coefficient of variation.

$$
\begin{aligned}
\text { NDFD } & =14.30+0.7643 C F D \pm 2.1 ; \\
R & =0.920 ; N=99 \\
A D F D & =-2.02+0.9693 C F D \pm 1.7 ; \\
R & =0.964 ; N=99
\end{aligned}
$$

\section{Relations between digestibility of the whole plant and of its principal constituents}

The relations were studied using the measurements mentioned above.

The cell content (proteins, soluble carbohydrates, starch, lipids) that is considered as the fraction of dry matter soluble in neutral detergent $(S=1000-N D F$ in $\mathrm{g} / \mathrm{kg}$
DM) have a high apparent digestibility ( $S D$ in percent $=81 \pm 2$ ), which increases linearly with $S$ content:

$$
\begin{aligned}
S D & =55.2+0.04778 S \pm 1.0 ; R=0.882 \\
N & =99
\end{aligned}
$$

As in the case of crude protein, there is thus a close relation between the digestible " $S$ " content ( $S D$ in $\mathrm{g} / \mathrm{kg} D M$ ) and the plant " $S$ " content:

$$
\begin{aligned}
D S & =1.0535 S-131 \pm 5 ; R=0.992 \\
N & =99
\end{aligned}
$$

This regression shows that the true digestibility of the soluble fraction is almost $100 \%$ but that the apparent digestion is rather 
less, due to faecal excretion of $131 \mathrm{~g} / \mathrm{kg}$ DM intake of soluble constituents of microbial and endogenous (metabolic) origin.

The fact that the cell content has an almost complete true digestibility and that metabolic faecal excretion is almost constant explains why the quantity of undigested $O M$ excreted per $\mathrm{kg} D M$ intake and thus the $O M D$, depends largely on the undigested cell-wall content (UNDF in $\mathrm{g} / \mathrm{kg}$ DM):

$$
\begin{aligned}
O M D & =92.94-0.1028 \text { UNDF } \pm 0.66 \\
R & =0.981 ; N=99 ; \text { fig } 8
\end{aligned}
$$

As a result, methods of prediction only give a correct idea of in vivo OMD if they take into account variations in undigested cell wall contents.

The equations relating in vivo $O M D$ with chemical composition or enzymatic solubility will not be given here (see Dardenne et al, 1993). However, it appeared of interest to use the limited but complete data to compare correlations between digestibility (in vivo or enzymatic) and the main explanatory or predictive variables (fig 9). For the reasons mentioned above, the cor- relations between in vivo $O M D$ with grain contents and cytoplasmic constituent contents considered separately (proteins, starch) are weaker than those between the same $O M D$ and the different cell-wall constituents (in particular lignin) or the in vivo digestibility of cell-wall constituents (in particular NDFD). For chemical methods, the best correlation ( $R=0.804 ; N=99)$ is obtained by associating, in the same equation, total cell-wall content (NDF) and the degree of lignification (ADL/NDF). This correlation is, however, lower than that involving the undigested cell wall content $(R=$ 0.981 ) for 2 reasons: first, because the digestibility of total cell walls, which was $58 \%$ \pm 5 on average, is independent of their content in the plant and, more especially, because the correlation between total cell wall digestibility and their degree of lignification is much weaker $(R=0.391$ or 0.681 , according to whether the hybrids carrying the gene bm 3 are eliminated or not - table VII) than that generally observed with forage crops (Van Soest, 1967).

Similarly, enzymatic solubility, by whatever method used, provides a poor reflection of in vivo OMD (see Appendix 2 and 3;

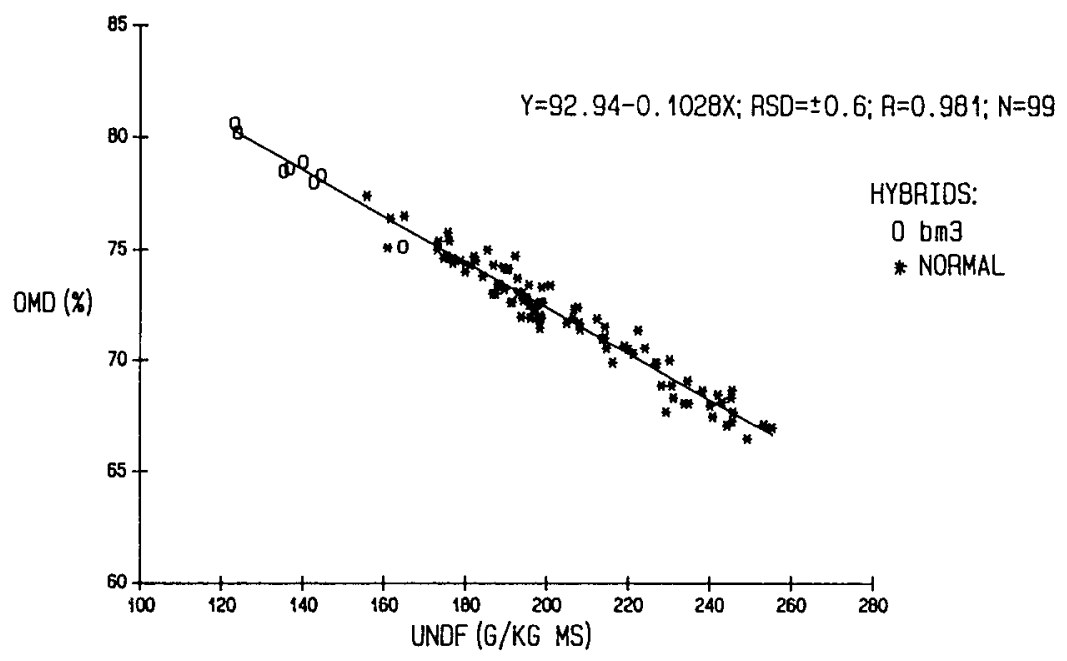

Fig 8. Relationship between $O M D$ of maize plant and its undigested cell-wall content (UNDF). 
Table VII. Correlation coefficients between apparent digestibility of the main plant constituents and the extent of cell wall lignification.

\begin{tabular}{|c|c|c|c|c|c|c|c|c|c|}
\hline \multirow{3}{*}{$\begin{array}{l}\text { Y } \quad X \\
\text { Apparent } \\
\text { digestibility }\end{array}$} & \multicolumn{3}{|c|}{$A D L N D F$} & \multicolumn{3}{|c|}{$A D L / A D F$} & \multicolumn{3}{|c|}{$\log A D L / A D F$} \\
\hline & \multicolumn{2}{|l|}{ Maize * } & \multirow{2}{*}{$\begin{array}{l}\text { Other } \\
\text { plants }\end{array}$} & \multicolumn{2}{|l|}{ Maize } & \multirow{2}{*}{$\begin{array}{l}\text { Other } \\
\text { plants }\end{array}$} & \multicolumn{2}{|l|}{ Maize } & \multirow{2}{*}{$\begin{array}{l}\text { Other } \\
\text { plants }\end{array}$} \\
\hline & $-b m 3$ & $+b m 3$ & & $-b m 3$ & $+b m 3$ & & $-b m 3$ & $+b m 3$ & \\
\hline$S^{* * * *}$ & $0.34^{b+\ldots *}$ & $0.32^{b}$ & NS & $0.20^{\mathrm{a}}$ & $0.23^{a}$ & NS & NS & NS & NS \\
\hline NDF & $0.39^{b}$ & $0.68^{b}$ & $0.90^{\mathrm{b}}$ & $0.34^{b}$ & $0.68^{b}$ & $0.95^{\mathrm{b}}$ & $0.35^{b}$ & $0.69^{b}$ & $0.98^{b}$ \\
\hline$N D F-A D F$ & $0.56^{\mathrm{b}}$ & $0.71^{b}$ & $0.87^{b}$ & $0.32^{b}$ & $0.60^{b}$ & $0.93^{b}$ & $0.32^{b}$ & $0.60^{\mathrm{b}}$ & $0.96^{\mathrm{b}}$ \\
\hline$A D F$ & NS & $0.51^{\mathrm{b}}$ & $0.86^{\mathrm{b}}$ & $0.25^{\mathrm{a}}$ & $0.63^{b}$ & $0.93^{b}$ & $0.26^{a}$ & $0.65^{b}$ & $0.95^{b}$ \\
\hline$C F$ & NS & $0.56^{\mathrm{b}}$ & $0.83^{b}$ & $0.31^{\mathrm{b}}$ & $0.65^{b}$ & $0.91^{\mathrm{b}}$ & $0.32^{b}$ & $0.67^{b}$ & $0.93^{b}$ \\
\hline$A D F-A D L$ & NS & $0.54^{b}$ & $0.87^{b}$ & $0.28^{b}$ & $0.62^{b}$ & $0.93^{b}$ & $0.29^{b}$ & $0.63^{b}$ & $0.96^{\mathrm{b}}$ \\
\hline
\end{tabular}

" Without or with the bm3 maize hybrid; "* Van Soest, 1967; "** a significant $P=0.05,{ }^{\text {b }}$ significant $P=0.01$; NS: non significant; "*** $\mathrm{S}=$ cell content.
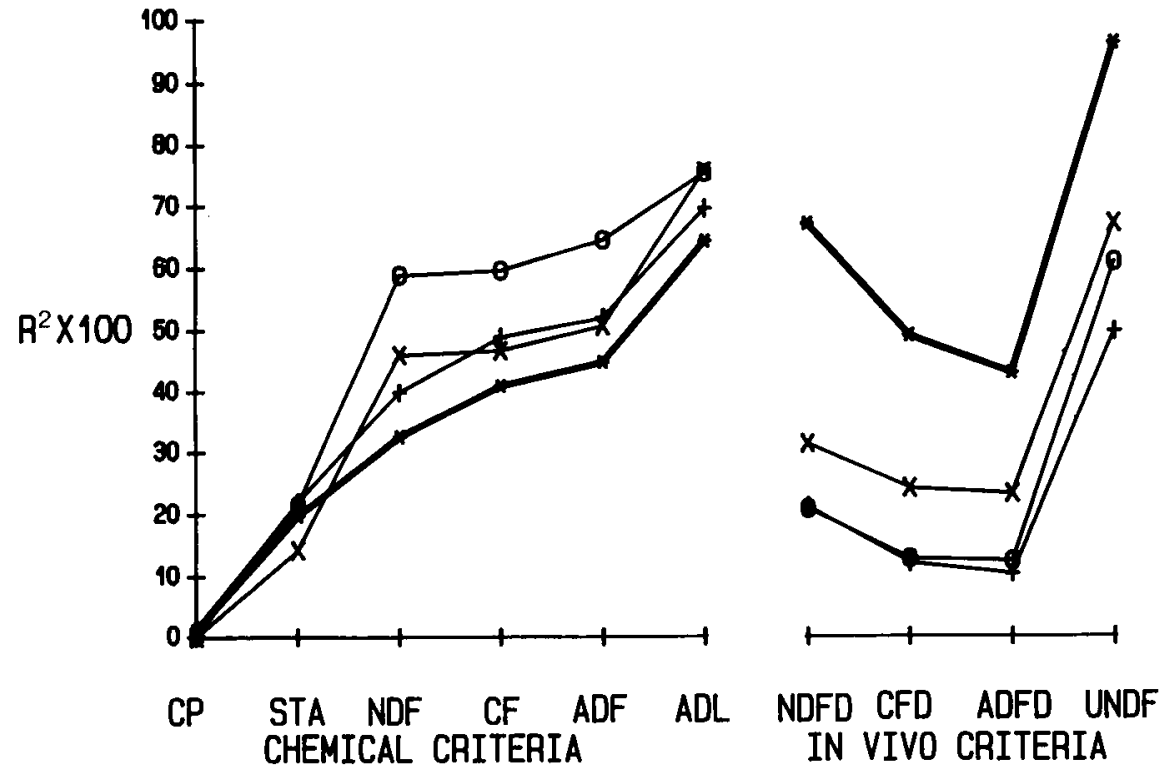

Fig 9. Correlations ( $R$ squared $\times 100$ ) between $O M D$ or enzymatic solubilities and chemical composition, digestibility of NDF, CF, ADF (NDFD, CFD, ADFD) or undigested NDF content (UNDF). 
and Barrière et al, 1991; Dardenne et al, 1993). This results mainly from the fact that it is more closely correlated with cell wall contents ( $R$ between 0.63 and 0.77 , according to method) than with their digestibility ( $R$ between 0.46 and 0.56 ).

\section{DISCUSSION}

After flowering, the digestibility of a maize plant may increase, decrease or remain constant, according to growing conditions (Struik, 1983). When the latter are favorable (water and temperature not limiting factors), the rapid and considerable development of grain results, as at ClermontFerrand, Lusignan and Toulouse, in a considerable increase in the ratio of cytoplasmic carbohydrates cell wall constituents, and thus of digestibility (fig 10). However, as the results obtained at ClermontFerrand in 1987 show, this increase is all the greater when the digestibility is low at the beginning of grain formation. This change, which had not been observed in earlier studies in comparable conditions (Demarquilly and Andrieu, 1973) had perhaps been covered by greater digestive interactions, due to ad libitum feeding without any nitrogen and mineral supplement. In contrast, when grain maturation is slower (as at Rennes, Le Pin and La Jaillère) due to less favorable climatic conditions (insufficient temperature, drought), digestibility does not change according to age, since the ratio of cytoplasmic and cell wall constituents varies to a much smaller extent (fig 10). Even if some starch accumulates in the grain, this accumulation is much slower and is based on transformation of carbohydrates synthesized before flowering and stored in the stem bases. In still more extreme conditions, particularly when photosynthesis stops due to destruction of leaves by an early frost (Andrieu, 1976), the digestibility of the plant decreases with age.

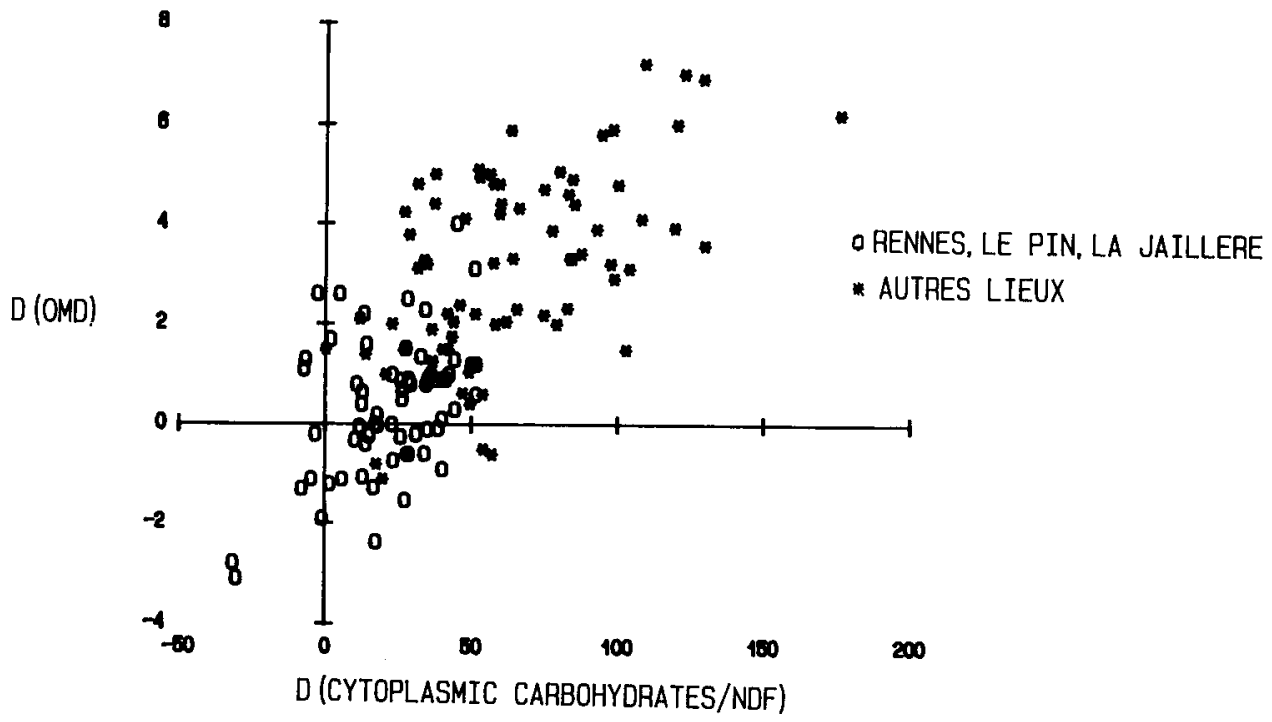

Fig 10. Relationship between increase in organic matter digestibility $(D(O M D)$ in points) and relative increase in \% of cytoplasmic carbohydrate/NDF ratio (the first crop of each maize variety is considered as base). 
However, climatic conditions after flowering do not provide a complete explanation of differences in digestibility observed at silage-making for maize genotypes grown in different environments (location, year). As shown by Struik (1983), the effect of climatic factors may induce large differences in digestibility at flowering, differences which remain, more or less, until harvest, according to later growing conditions. As indicated by the large differences in digestibility observed between years for crops when little change occurred after flowering (Rennes), the year factor may induce, at flowering, large differences in the undigestible cell wall content of the plant. However, it should be noted, without any evident explanation, that the year effect was not in the same direction at Rennes as in the other locations. The relation (cause or effect) with the lodging observed at Rennes in 1988 has not been clearly established.

Of climatic factors, temperature is certainly one of the most important since it affects the content of cell walls and its digestibility (Dirven and Deinum, 1977) and grain development (Ragland et al, 1965). Temperature can have a very variable effect according to plant physiological stage and to the duration of particular temperature levels. However, according to Struik et al (1985) the depressive effect of high temperatures on digestibility is of particular importance during the growth phase from 7 to 8 leaves to grain filling.

By not taking into account the hybrid bm3, the digestibility of the commercial hybrids was very similar to that observed 20 $\mathrm{yr}$ earlier for different hybrids. For single locations and years, there are significant differences in digestibility between hybrids, but these result from differences in undigested cell wall contents which may not be found the following year in the same location or the same year in a different loca- tion. This is due to the fact that demonstration of a genotype effect was not the main objective of the experimental design. In addition, the differences, when they exist, are small in relation to the precision of measurements, which is poorer for maize than for other forage crops (Deinum, 1984). For enzymatic solubilities, the significant differences that appear between hybrids are not necessarily found in vivo (Appendix 2, 3). Their use in breeding work thus needs confirmation by measurements on animals.

The present results confirm that maize (Diven et Deinum, 1977) and other forage crops (Jarrige and Minson, 1964; Van Soest and Moore, 1965) show a number of common characteristics, in particular the complete true digestion of cell content, and the close correlation which results from this between OM digestibility and undigested cell-wall content. However, the present results indicate that in other aspects, maize and other forage crops are considerably different at the growth stages where they are usually harvested for conservation. In particular, maize cell walls, which constitute a smaller part of plant DM have a composition which is not only different (lower cellulose content, higher mean hemicellulose/cellulose ratio), but also less variable with age. Their degree of lignification remains almost constant due to the effect of grain dilution. In addition, the digestibility of maize cell walls is, in contrast with that of other forage crops, almost independent of their content in the plant, and, more especially much less related to their degree of lignification (table VII). Such a result explains why enzymatic methods, which depend largely on cell-wall content, are much less satisfactory for maize then for other forage species. Finally, and more particularly, the digestibility of maize cell walls is, for a given lignification (ADLADF ratio) much less (by a mean of at least 10 points) than that of other species (fig 11). This results mainly from the fact that cellulose di- 
gestibility is on average 4 points lower than that of hemicellulose. Several hypotheses have been put forward to explain the lower digestibility of maize cell walls, in particular the possible negative influence of high contents in cytoplasmic carbohydrates on the cellulolytic activity of the rumen liquid. However, the fact that $A D L$ contains only part of the lignin may also be important: according to Engels and Cones (1989), ADL may be constituted by core lignin and certain authors (Buritt et al, 1974; Jung and Fahey, 1984) have shown that other less elaborated forms (non-core lignin) may reduce cell-wall digestibility.

\section{CONCLUSION}

During the vegetation phase considered in this study, the differences in digestibility between maize crops are relatively low and often of the same magnitude of accuracy as the in vivo measurement method.
In fact, it is difficult to identify the sources of variation, for example the influence of the hybrid. In the context of the present study, similar conclusions were obtained as those found $15 \mathrm{yr}$ ago with different vegetative material, for the hybrid effect is seldom significant for a given location. If so, it is of the same magnitude as those of location and year of the hybrid given.

This study illustrates the importance of cell walls and especially their digestibility, which is indicative of the digestibility of the whole plant.

A study on the factors that determine the variability in in vivo digestibility of the plant cell wall at the silage stage is of interest, but is a complex undertaking. Measurements of digestibility have to be carried out with taking into account the interactions between digestibility of cell walls and cell contents (soluble sugars and starch); and an applicable in vitro method to measure this digestibility is also required.

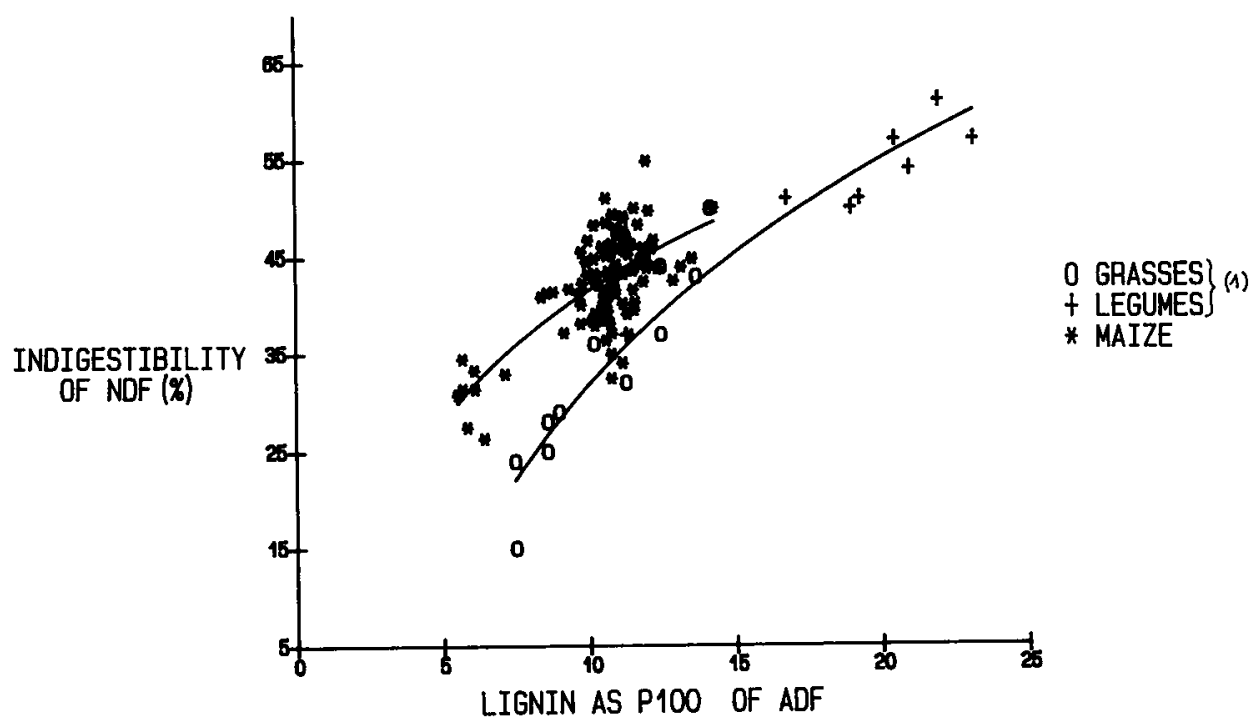

Fig 11. Relationship between indigestibility (fecal NDF: \% forage intake $N D F$ ) and lignin concentration in $A D F$. 
Appendix 2a. Effect ( $F$ values) of year $(Y)$, hybrid $(H)$, and dry matter content (DM) on chemical composition and nutritive value of maize grown at Clermond-Ferrand.

\begin{tabular}{|c|c|c|c|c|c|c|c|}
\hline \multirow[t]{2}{*}{ Variates * } & \multicolumn{2}{|c|}{ Factorials } & \multicolumn{3}{|c|}{ Interactions } & \multicolumn{2}{|c|}{ Covariates } \\
\hline & $Y$ & $H$ & $Y \times H$ & $Y \times D M$ & $H \times D M$ & $D M$ & $D M^{2}$ \\
\hline$A S H$ & NS & $2.7^{\mathrm{a}}$ & NS & NS & NS & $125.2^{b}$ & NS \\
\hline$C P$ & $216.3^{b}$ & NS & NS & $37.7^{\circ}$ & NS & $9.6^{b}$ & NS \\
\hline GRA & 19.10 & $9.6^{\mathrm{b}}$ & NS & NS & NS & $60.2^{\circ}$ & $38.2^{\mathrm{b}}$ \\
\hline STA & $47.1^{\mathrm{b}}$ & $8.0^{\mathrm{b}}$ & NS & NS & NS & $79.1^{b}$ & $53.7^{\mathrm{b}}$ \\
\hline WSC & $89.8^{b}$ & $2.9^{a}$ & NS & NS & NS & $43.2^{b}$ & $26.3^{\mathrm{b}}$ \\
\hline NDF & NS & NS & NS & NS & NS & $54.6^{b}$ & NS \\
\hline$A D F$ & $9.8^{b}$ & $3.4^{a}$ & NS & NS & NS & $83.3^{b}$ & NS \\
\hline$C F$ & NS & $3.7^{\mathrm{a}}$ & NS & NS & NS & $74.4^{b}$ & NS \\
\hline$A D L$ & $5.7^{a}$ & $5.4^{b}$ & NS & NS & NS & $64.1^{\circ}$ & NS \\
\hline \multicolumn{8}{|l|}{ Solubility } \\
\hline$A \cup F$ & $10.3^{b}$ & $11.1^{\mathrm{b}}$ & NS & NS & NS & $26.2^{b}$ & $19.5^{\mathrm{b}}$ \\
\hline LGS & $6.6^{\mathrm{a}}$ & $11.2^{\mathrm{b}}$ & NS & NS & NS & $21.1^{b}$ & $16.3^{\mathrm{b}}$ \\
\hline$A P C$ & NS & $6.9^{\mathrm{b}}$ & NS & NS & NS & $8.6^{\mathrm{b}}$ & $5.6^{\mathrm{a}}$ \\
\hline \multicolumn{8}{|l|}{ Digestibility } \\
\hline$O M$ & $51.3^{b}$ & $20.7^{b}$ & NS & NS & NS & $37.3^{b}$ & $29.6^{\mathrm{b}}$ \\
\hline$C F$ & $18.1^{\mathrm{b}}$ & $16.4^{b}$ & NS & NS & NS & NS & NS \\
\hline
\end{tabular}

* For abbreviations see table IV. NS: non significant; a significant at $P=0.05$; ${ }^{b}$ significant at $P=0.01$.

Appendix 2b. Effect ( $F$ values) of year $(Y)$, hybrid $(H)$, and dry matter content (DM) on chemical composition and nutritive value of maize grown at Rennes.

\begin{tabular}{|c|c|c|c|c|c|c|c|}
\hline \multirow[t]{2}{*}{ Variates * } & \multicolumn{2}{|c|}{ Factorials } & \multicolumn{3}{|c|}{ Interactions } & \multicolumn{2}{|c|}{ Covariates } \\
\hline & $Y$ & $H$ & $Y \times H$ & $Y \times D M$ & $H \times D M$ & $D M$ & $D M^{2}$ \\
\hline ASH & $108.2^{b}$ & NS & NS & NS & NS & $11.7^{b}$ & NS \\
\hline$C P$ & NS & $11.5^{\mathrm{b}}$ & NS & NS & NS & NS & NS \\
\hline GRA & NS & $5.1^{\mathrm{a}}$ & NS & $9.6^{\mathrm{b}}$ & NS & $58.7^{\mathrm{b}}$ & NS \\
\hline STA & NS & NS & NS & $11.0^{\mathrm{b}}$ & NS & $52.7^{\mathrm{b}}$ & NS \\
\hline WSC & NS & NS & NS & NS & NS & $21.9^{b}$ & NS \\
\hline NDF & $9.7^{b}$ & $6.7^{b}$ & NS & $12.0^{\mathrm{b}}$ & NS & $20.3^{\mathrm{b}}$ & NS \\
\hline$A D F$ & NS & NS & NS & $11.8^{\mathrm{b}}$ & NS & $37.5^{\mathrm{b}}$ & NS \\
\hline$C F$ & $6.4^{\mathrm{a}}$ & NS & NS & $8.6^{\mathrm{b}}$ & NS & $11.3^{\mathrm{b}}$ & NS \\
\hline$A D L$ & NS & NS & NS & $6.1^{b}$ & NS & $19.1^{b}$ & NS \\
\hline \multicolumn{8}{|l|}{ Solubility } \\
\hline$A \cup F$ & $9.4^{b}$ & NS & NS & NS & NS & $8.1^{a}$ & $7.0^{\mathrm{a}}$ \\
\hline LGS & $22.5^{\mathrm{b}}$ & $8.5^{\mathrm{b}}$ & NS & NS & NS & $9.4^{b}$ & $7.9^{\mathrm{a}}$ \\
\hline$A P C$ & $21.0^{\mathrm{b}}$ & NS & NS & NS & NS & $7.1^{\mathrm{a}}$ & NS \\
\hline \multicolumn{8}{|l|}{ Digestibility } \\
\hline$O M$ & $88.6^{b}$ & NS & NS & $11.1^{b}$ & NS & NS & NS \\
\hline$C F$ & $43.7^{b}$ & NS & NS & NS & NS & NS & NS \\
\hline
\end{tabular}

\footnotetext{
${ }^{*}$ For abbreviations, see table IV. NS: non significant; ${ }^{a}$ significant at $P=0.05 ;{ }^{b}$ significant at $P=0.01$
} 
Appendix 2c. Effect ( $F$ values) of year $(\mathrm{Y})$, hybrid $(\mathrm{H})$ and dry matter content (DM) on chemical composition and nutritive value of maize grown at Lusignan.

\begin{tabular}{|c|c|c|c|c|c|c|c|}
\hline \multirow[t]{2}{*}{ Variates * } & \multicolumn{2}{|c|}{ Factorials } & \multicolumn{3}{|c|}{ Interactions } & \multicolumn{2}{|c|}{ Covariates } \\
\hline & $Y$ & $H$ & $Y \times H$ & $Y \times D M$ & $H \times D M$ & $D M$ & $D M^{2}$ \\
\hline$A S H$ & $22.9^{b}$ & $10.0^{\mathrm{b}}$ & $5.1^{\mathrm{b}}$ & NS & NS & $60.6^{\mathrm{b}}$ & NS \\
\hline$C P$ & $126.4^{\mathrm{b}}$ & $23.0^{\mathrm{b}}$ & $7.1^{b}$ & NS & NS & $34.0^{\mathrm{b}}$ & NS \\
\hline GRA & $65.0^{\mathrm{b}}$ & NS & $5.6^{b}$ & NS & $4.5^{\mathrm{b}}$ & $97.6^{\mathrm{b}}$ & $63.4^{b}$ \\
\hline STA & $32.9^{\mathrm{b}}$ & NS & $3.6^{a}$ & NS & NS & $36.4^{b}$ & $24.2^{\mathrm{b}}$ \\
\hline WSC & $8.9^{b}$ & NS & NS & $7.0^{\mathrm{b}}$ & $4.4^{b}$ & $84.5^{\mathrm{b}}$ & NS \\
\hline NDF & $4.9^{\mathrm{a}}$ & $3.4^{\mathrm{a}}$ & $3.0^{a}$ & NS & NS & $72.9^{b}$ & NS \\
\hline$A D F$ & $10.1^{\mathrm{b}}$ & $8.4^{b}$ & $3.8^{a}$ & NS & NS & $65.3^{b}$ & NS \\
\hline$C F$ & $12.1^{b}$ & $7.2^{b}$ & $2.9^{a}$ & NS & NS & $51.5^{b}$ & NS \\
\hline$A D L$ & $13.0^{\mathrm{b}}$ & $55.0^{\mathrm{b}}$ & $4.9^{b}$ & NS & NS & $49.5^{b}$ & NS \\
\hline \multicolumn{8}{|l|}{ Solubility } \\
\hline$A \cup F$ & NS & $65.2^{\mathrm{b}}$ & $10.1^{b}$ & NS & NS & $14.6^{\mathrm{b}}$ & $11.3^{b}$ \\
\hline LGS & $23.2^{b}$ & $88.2^{\mathrm{b}}$ & $5.1^{b}$ & NS & NS & $18.3^{\mathrm{b}}$ & $14.9^{\mathrm{b}}$ \\
\hline$A P C$ & NS & $72.5^{\mathrm{b}}$ & NS & NS & NS & $9.5^{\mathrm{b}}$ & $7.1^{\mathrm{a}}$ \\
\hline \multicolumn{8}{|l|}{ Digestibility } \\
\hline$O M$ & $82.2^{\mathrm{b}}$ & $82.5^{\mathrm{b}}$ & $3.7^{\mathrm{a}}$ & NS & NS & $20.0^{\mathrm{b}}$ & $14.4^{b}$ \\
\hline$C F$ & $24.6^{\mathrm{b}}$ & $43.6^{\mathrm{b}}$ & NS & $4.8^{a}$ & NS & NS & NS \\
\hline
\end{tabular}

* For abbreviations, see table IV. NS: nen significant; a significant at $P=0.05$; ${ }^{\mathrm{b}}$ significant at $P=0.01$.

Appendix 2d. Effect (F values) of year $(Y)$, hybrid $(H)$, and dry matter content (DM) on chemical composition and nutritive value of maize grown at Le Pin-au-Haras.

\begin{tabular}{|c|c|c|c|c|c|c|c|}
\hline \multirow[t]{2}{*}{ Variates * } & \multicolumn{2}{|c|}{ Factorials } & \multicolumn{3}{|c|}{ Interactions } & \multicolumn{2}{|c|}{ Covariates } \\
\hline & $Y$ & $H$ & $Y \times H$ & $Y \times D M$ & $H \times D M$ & $D M$ & $D M^{2}$ \\
\hline$A S H$ & NS & $5.0^{\mathrm{b}}$ & NS & NS & $3.0^{a}$ & NS & NS \\
\hline$C P$ & $25.8^{\mathrm{b}}$ & $24.9^{b}$ & $3.3^{a}$ & NS & NS & NS & NS \\
\hline GRA & NS & NS & NS & $4.7^{a}$ & NS & $24.3^{b}$ & NS \\
\hline STA & NS & NS & $4.6^{\mathrm{a}}$ & NS & NS & $19.6^{b}$ & NS \\
\hline WSC & $24.7^{\mathrm{b}}$ & NS & NS & $8.9^{b}$ & NS & $8.3^{b}$ & NS \\
\hline$N D F$ & $15.4^{b}$ & NS & NS & NS & NS & $7.5^{\mathrm{b}}$ & NS \\
\hline$A D F$ & NS & NS & $5.4^{\mathrm{b}}$ & NS & NS & $13.2^{b}$ & NS \\
\hline$C F$ & NS & $4.9^{b}$ & $9.2^{\mathrm{b}}$ & NS & NS & $21.5^{b}$ & NS \\
\hline$A D L$ & $18.9^{\mathrm{b}}$ & NS & NS & NS & NS & NS & NS \\
\hline \multicolumn{8}{|l|}{ Solubility } \\
\hline$A \cup F$ & $10.7^{b}$ & NS & $10.5^{\mathrm{b}}$ & NS & NS & NS & NS \\
\hline LGS & $21.5^{\mathrm{b}}$ & $4.7^{b}$ & $4.2^{\mathrm{a}}$ & NS & NS & $17.8^{\mathrm{b}}$ & NS \\
\hline$A P C$ & $17.6^{\mathrm{b}}$ & NS & NS & NS & NS & NS & NS \\
\hline \multicolumn{8}{|l|}{ Digestibility } \\
\hline$O M$ & $14.3^{b}$ & $3.6^{a}$ & NS & $11.8^{b}$ & NS & $19.4^{b}$ & NS \\
\hline$C F$ & NS & $3.0^{a}$ & $9.5^{\mathrm{b}}$ & $9.1^{b}$ & NS & NS & NS \\
\hline
\end{tabular}

* For abbreviations see table IV. NS: non significant; a significant at $P=0.05$; ${ }^{b}$ significant at $P=0.01$. 
Appendix 2e. Effect ( $F$ values) of hybrid $(H)$ and dry matter content (DM) on chemical composition and nutritive value of maize grown at Dijon.

\begin{tabular}{|c|c|c|c|c|}
\hline \multirow[t]{2}{*}{ Variates * } & \multirow[t]{2}{*}{$\mathrm{H}$} & \multirow{2}{*}{$\frac{\text { Interactions }}{H \times D M}$} & \multicolumn{2}{|c|}{ Covariates } \\
\hline & & & $D M$ & $D M^{2}$ \\
\hline$A S H$ & $5.2^{\mathrm{a}}$ & $5.9^{\mathrm{a}}$ & $16.1^{\mathrm{b}}$ & NS \\
\hline$C P$ & $15.5^{b}$ & NS & $12.1^{\mathrm{a}}$ & NS \\
\hline GRA & $8.7^{a}$ & NS & $48.0^{b}$ & NS \\
\hline STA & NS & $10.5^{a}$ & $146.7^{\mathrm{b}}$ & NS \\
\hline WSC & $13.2^{\mathrm{b}}$ & $7.6^{\mathrm{a}}$ & $200.0^{\mathrm{b}}$ & NS \\
\hline NDF & NS & $7.2^{\mathrm{a}}$ & $73.8^{b}$ & NS \\
\hline$A D F$ & $6.7^{a}$ & $15.4^{b}$ & $100.2^{b}$ & NS \\
\hline$C F$ & NS & $6.0^{\mathrm{a}}$ & $42.5^{\mathrm{b}}$ & NS \\
\hline$A D L$ & $30.3^{b}$ & $17.4^{b}$ & $76.3^{b}$ & NS \\
\hline \multicolumn{5}{|l|}{ Solubility } \\
\hline$A \cup F$ & NS & $7.0^{\mathrm{a}}$ & $12.8^{\mathrm{a}}$ & NS \\
\hline LGS & $24.6^{\mathrm{b}}$ & $17.5^{\mathrm{b}}$ & $140.8^{b}$ & NS \\
\hline$A P C$ & NS & NS & $27.0^{\mathrm{b}}$ & NS \\
\hline \multicolumn{5}{|l|}{ Digestibility } \\
\hline$O M$ & NS & NS & $13.3^{b}$ & $12.0^{\mathrm{a}}$ \\
\hline $\mathrm{CF}$ & NS & NS & NS & NS \\
\hline
\end{tabular}

* For abbreviations see table IV. NS : non significant; a significant at $P=0.05$; ${ }^{\text {b }}$ significant at $P=0.01$.
Appendix 2g. Effect ( $F$ values) of hybrid $(H)$ and dry matter content (DM) on chemical composition and nutritive value of maize grown at Toulouse.

\begin{tabular}{|c|c|c|c|c|}
\hline \multirow[t]{2}{*}{ Variates * } & \multirow[t]{2}{*}{$H$} & \multirow{2}{*}{$\frac{\text { Interactions }}{H \times D M}$} & \multicolumn{2}{|c|}{ Covariates } \\
\hline & & & $D M$ & $D M^{2}$ \\
\hline ASH & $76.1^{\mathrm{b}}$ & NS & $33.0^{\mathrm{b}}$ & NS \\
\hline$C P$ & NS & $18.5^{b}$ & $93.1^{b}$ & NS \\
\hline GRA & $8.8^{a}$ & $38.3^{b}$ & $276.9^{\circ}$ & $188.8^{\mathrm{b}}$ \\
\hline STA & NS & $8.0^{\mathrm{a}}$ & $55.8^{\mathrm{b}}$ & $34.3^{b}$ \\
\hline WSC & $10.2^{\mathrm{b}}$ & NS & $31.9^{b}$ & NS \\
\hline NDF & $6.7^{a}$ & NS & $34.7^{b}$ & NS \\
\hline$A D F$ & $7.8^{\mathrm{a}}$ & NS & $33.8^{\mathrm{b}}$ & NS \\
\hline$C F$ & $11.3^{b}$ & NS & $43.0^{b}$ & NS \\
\hline$A D L$ & $20.3^{b}$ & NS & $40.6^{b}$ & NS \\
\hline \multicolumn{5}{|l|}{ Solubility } \\
\hline$A \cup F$ & $6.9^{\mathrm{a}}$ & NS & $18.1^{\mathrm{b}}$ & NS \\
\hline LGS & NS & $5.7^{\mathrm{a}}$ & $38.0^{\mathrm{b}}$ & $25.7^{\mathrm{b}}$ \\
\hline$A P C$ & NS & NS & NS & NS \\
\hline \multicolumn{5}{|c|}{ Digestibility } \\
\hline$O M$ & NS & NS & $17.4^{\mathrm{b}}$ & $15.1^{b}$ \\
\hline$C F$ & $6.7^{\mathrm{a}}$ & NS & NS & NS \\
\hline
\end{tabular}

* For abbreviations, see table IV. NS: non significant; ${ }^{3}$ significant at $P=0.05{ }^{\circ}$ significant at $P=0.01$.

Appendix 2f. Effect ( $F$ values) of year $(Y)$, hybrid $(H)$ and dry matter content $(D M)$ on chemical composition and nutritive value of maize grown at $L a$ Jaillère.

\begin{tabular}{|c|c|c|c|c|c|c|c|}
\hline \multirow[t]{2}{*}{ Variates * } & \multicolumn{2}{|c|}{ Factorials } & \multicolumn{3}{|c|}{ Interactions } & \multicolumn{2}{|c|}{ Covariates } \\
\hline & $\gamma$ & $H$ & $Y \times H$ & $Y X D M$ & $H \times D M$ & $D M$ & $D M^{2}$ \\
\hline$A S H$ & NS & NS & NS & NS & NS & NS & NS \\
\hline$C P$ & $291.4^{b}$ & NS & NS & NS & NS & NS & NS \\
\hline GRA & $3.3^{a}$ & $6.2^{b}$ & NS & $36.2^{\mathrm{b}}$ & $8.5^{\mathrm{b}}$ & $328.4^{b}$ & NS \\
\hline STA & $5.2^{\mathrm{a}}$ & NS & $6.8^{\mathrm{b}}$ & $56.4^{b}$ & $10.4^{b}$ & $152.7^{b}$ & NS \\
\hline WSC & NS & $4.3^{a}$ & NS & $30.8^{b}$ & $5.0^{\mathrm{b}}$ & $143.7^{b}$ & NS \\
\hline NDF & $5.6^{a}$ & $5.6^{a}$ & NS & $7.2^{\mathrm{b}}$ & NS & NS & NS \\
\hline$A D F$ & $6.4^{\mathrm{a}}$ & $9.1^{b}$ & $3.4^{\mathrm{a}}$ & $12.0^{\mathrm{b}}$ & NS & NS & NS \\
\hline$C F$ & $7.3^{a}$ & $15.0^{\mathrm{b}}$ & $3.9^{a}$ & $11.9^{\mathrm{b}}$ & NS & NS & NS \\
\hline$A D L$ & $14.2^{b}$ & $8.9^{b}$ & $4.7^{a}$ & NS & NS & NS & NS \\
\hline \multicolumn{8}{|l|}{ Solubility } \\
\hline$A \cup F$ & NS & $20.4^{b}$ & NS & NS & $3.6^{\mathrm{a}}$ & NS & NS \\
\hline LGS & NS & $14.4^{b}$ & NS & NS & NS & NS & NS \\
\hline$A P C$ & NS & $8.2^{\mathrm{b}}$ & NS & $6.8^{b}$ & NS & NS & NS \\
\hline \multicolumn{8}{|l|}{ Digestibility } \\
\hline$O M$ & $94.4^{b}$ & NS & NS & $21.5^{\mathrm{b}}$ & $5.4^{b}$ & NS & NS \\
\hline$C F$ & $13.3^{b}$ & NS & NS & NS & NS & NS & NS \\
\hline
\end{tabular}

* For abbreviations see table IV. NS: non significant; ${ }^{a}$ significant at $P=0.05{ }^{b}$ significant at $P=0.01$. 
Appendix 3a. Effect ( $F$ values) of year $(Y)$, location (L) (Clermont and Lusignan), hybrid $(H)(1,4)$ and dry matter (DM) on chemical composition and nutritive value.

\begin{tabular}{|c|c|c|c|c|c|c|c|c|c|c|}
\hline \multirow[t]{2}{*}{ Variates * } & \multicolumn{3}{|c|}{ Factorials } & \multicolumn{6}{|c|}{ Interactions } & \multirow{2}{*}{$\begin{array}{l}\text { Covariate } \\
D M\end{array}$} \\
\hline & $Y$ & $L$ & $H$ & $Y \times L$ & $Y \times H$ & $L \times H$ & $Y \times D M$ & $L \times D M$ & $H \times D M$ & \\
\hline$A S H$ & NS & $176.3^{\circ}$ & $11.3^{b}$ & NS & NS & NS & NS & NS & NS & $36.3^{b}$ \\
\hline$C P$ & $77.1^{\mathrm{b}}$ & $33.6^{b}$ & NS ${ }^{a}$ & NS & NS & NS & $6.7^{\mathrm{a}}$ & NS & NS & $14.0^{\mathrm{b}}$ \\
\hline GRA & $4.8^{\mathrm{a}}$ & NS & $6.0^{\mathrm{a}}$ & NS & NS & NS & NS & NS & NS & $102.0^{\mathrm{b}}$ \\
\hline STA & $10.6^{\mathrm{b}}$ & NS & $6.0^{a}$ & $5.8^{a}$ & NS & NS & NS & NS & NS & $82.7^{b}$ \\
\hline WSC & $30.2^{\mathrm{b}}$ & $19.3^{b}$ & $7.1^{\mathrm{a}}$ & NS & NS & NS & NS & NS & NS & $112.2^{b}$ \\
\hline$N D F$ & $5.1^{\mathrm{a}}$ & $16.6^{\mathrm{b}}$ & 4.2 & $5.8^{a}$ & NS & NS & NS & NS & NS & $46.9^{b}$ \\
\hline$A D F$ & $13.7^{b}$ & $5.6^{a}$ & NS & $5.1^{a}$ & NS & NS & NS & NS & NS & $39.9^{b}$ \\
\hline$C F$ & $7.4^{\mathrm{a}}$ & NS & NS & $9.5^{b}$ & NS & NS & NS & NS & NS & $30.7^{b}$ \\
\hline$A D L$ & $19.2^{b}$ & $5.3^{a}$ & NS & $4.2^{a}$ & NS & NS & NS & NS & $6.2^{\mathrm{a}}$ & $44.6^{\mathrm{b}}$ \\
\hline \multicolumn{11}{|l|}{ Solubility } \\
\hline$A \cup F$ & NS & $30.5^{\mathrm{b}}$ & NS & $6.4^{\mathrm{b}}$ & NS & NS & NS & NS & NS & $17.4^{b}$ \\
\hline LGS & $10.7^{b}$ & $37.7^{\mathrm{b}}$ & NS & $13.5^{b}$ & NS & NS & NS & NS & NS & $19.5^{b}$ \\
\hline$A P C$ & NS & NS & $10.4^{b}$ & NS & NS & NS & NS & NS & NS & $21.8^{b}$ \\
\hline \multicolumn{11}{|l|}{ Digestibility } \\
\hline$O M$ & $15.2^{b}$ & $11.2^{b}$ & NS & NS & NS & $4.3^{a}$ & NS & NS & NS & $24.7^{b}$ \\
\hline$C F$ & $8.6^{\mathrm{b}}$ & $10.0^{\mathrm{b}}$ & $4.7^{\mathrm{a}}$ & NS & NS & NS & NS & NS & NS & NS \\
\hline
\end{tabular}

* For abbreviations, see table IV. NS: non significant; ${ }^{a}$ significant at $P=0.05$; $^{\mathrm{b}}$ significant at $P=0.01$.

Appendix 3b. Effect ( $F$ values) of year $(Y)$, location $(L)$ (Rennes and La Jaillère), hybrid $(H)(2,10)$ and dry matter (DM) on chemical composition and nutritive value.

\begin{tabular}{|c|c|c|c|c|c|c|c|c|c|c|}
\hline \multirow[t]{2}{*}{ Variates * } & \multicolumn{3}{|c|}{ Factorials } & \multicolumn{6}{|c|}{ Interactions } & \multirow{2}{*}{$\begin{array}{c}\text { Covariate } \\
D M\end{array}$} \\
\hline & $Y$ & $L$ & $H$ & $Y \times L$ & $Y \times H$ & $L \times H$ & $Y \times D M$ & $\angle x D M$ & $H \times D M$ & \\
\hline$A S H$ & $18.2^{\mathrm{b}}$ & NS & NS & $16.8^{\mathrm{b}}$ & NS & NS & NS & $15.8^{b}$ & NS & $19.7^{b}$ \\
\hline$C P$ & $66.4^{b}$ & NS & $24.6^{\mathrm{b}}$ & $95.7^{b}$ & NS & NS & $8.5^{\mathrm{b}}$ & NS & NS & NS \\
\hline GRA & NS & $19.6^{b}$ & $7.5^{\mathrm{a}}$ & NS & NS & NS & NS & $7.8^{\mathrm{b}}$ & $6.2^{\mathrm{a}}$ & $75.3^{\mathrm{b}}$ \\
\hline$S T A$ & NS & $5.9^{\mathrm{a}}$ & NS & $4.9^{\mathrm{a}}$ & NS & NS & $5.4^{\mathrm{a}}$ & $9.3^{b}$ & $4.5^{\mathrm{a}}$ & 40.4 \\
\hline WSC & NS & NS & NS & NS & NS & NS & $4.6^{a}$ & NS & NS & $30.3^{b}$ \\
\hline$A D F$ & NS & NS & $5.9^{\mathrm{a}}$ & $14.7^{\mathrm{b}}$ & NS & $4.2^{\mathrm{a}}$ & $5.7^{\mathrm{a}}$ & $12.3^{\mathrm{b}}$ & $4.5^{\mathrm{a}}$ & $14.0^{\mathrm{b}}$ \\
\hline$C F$ & NS & NS & NS & $9.1^{\mathrm{b}}$ & NS & NS & NS & NS & NS & NS \\
\hline$A D L$ & NS & NS & $9.3^{b}$ & $5.5^{\mathrm{a}}$ & NS & $6.0^{\mathrm{a}}$ & NS & $7.2^{\mathrm{b}}$ & NS & $4.4^{\mathrm{a}}$ \\
\hline \multicolumn{11}{|l|}{ Solubility } \\
\hline$A \cup F$ & NS & NS & NS & $4.2^{\mathrm{a}}$ & NS & $4.5^{\mathrm{a}}$ & NS & NS & NS & NS \\
\hline LGS & $26.1^{\mathrm{b}}$ & NS & $29.1^{b}$ & NS & NS & NS & NS & $7.2^{\mathrm{a}}$ & NS & $5.9^{a}$ \\
\hline$A P C$ & $14.9^{\mathrm{b}}$ & NS & $8.0^{\mathrm{b}}$ & $11.6^{\mathrm{b}}$ & NS & NS & NS & NS & NS & NS \\
\hline \multicolumn{11}{|c|}{ Digestibility } \\
\hline$O M$ & NS & $11.1^{b}$ & NS & $47.7^{\mathrm{b}}$ & NS & NS & NS & NS & NS & NS \\
\hline$C F$ & $4.9^{\mathrm{a}}$ & NS & NS & $11.0^{\mathrm{b}}$ & NS & NS & NS & NS & NS & NS \\
\hline
\end{tabular}

- For abbreviations, see table IV. NS non significant; a significant at $P=0.05$; ${ }^{\mathrm{b}}$ significant at $P=0.01$. 
Appendix 3c. Effect ( $F$ values) of year $(Y)$, location $(L)$ (Lusignan and La Jaillère), hybrid $(H)(1,5)$ and dry matter (DM) on chemical composition and nutritive value.

\begin{tabular}{|c|c|c|c|c|c|c|c|c|c|c|}
\hline \multirow[t]{2}{*}{ Variates * } & \multicolumn{3}{|c|}{ Factorials } & \multicolumn{6}{|c|}{ Interactions } & \multirow{2}{*}{$\begin{array}{c}\text { Covariate } \\
D M\end{array}$} \\
\hline & $Y$ & $L$ & $H$ & $Y \times L$ & $Y \times H$ & $L \times H$ & $Y \times D M$ & $L \times D M$ & $H \times D M$ & \\
\hline$A S H$ & NS & $35.3^{b}$ & NS & $5.1^{a}$ & NS & NS & NS & $9.1^{b}$ & NS & $16.1^{\mathrm{b}}$ \\
\hline$C P$ & $130.3^{b}$ & $12.3^{b}$ & $12.6^{b}$ & $38.2^{\circ}$ & NS & NS & NS & NS & NS & $8.1^{b}$ \\
\hline GRA & $8.7 \mathrm{~b}$ & $14.7^{\mathrm{b}}$ & NS & NS & $4.5^{\mathrm{a}}$ & $6.9^{a}$ & $18.0^{\mathrm{b}}$ & $5.1^{\mathrm{a}}$ & $7.1^{\mathrm{a}}$ & $227.4^{b}$ \\
\hline STA & $11.0^{\mathrm{b}}$ & $10.4^{\mathrm{b}}$ & NS & NS & $6.1^{\mathrm{a}}$ & NS & $11.3^{a}$ & $8.2^{b}$ & NS & $91.5^{\mathrm{b}}$ \\
\hline WSC & NS & NS & NS & NS & NS & NS & $6.4^{\mathrm{a}}$ & NS & $8.3^{b}$ & $45.4^{b}$ \\
\hline$N D F$ & $6.2^{\mathrm{a}}$ & $60.8^{b}$ & $4.9^{a}$ & NS & NS & NS & NS & $23.9^{b}$ & NS & $23.5^{b}$ \\
\hline$A D F$ & $10.3^{b}$ & $37.1^{\circ}$ & NS & NS & $7.9^{b}$ & NS & NS & $16.5^{\mathrm{b}}$ & NS & $25.0^{\mathrm{b}}$ \\
\hline$C F$ & $10.1^{b}$ & $66.9^{\mathrm{b}}$ & $9.4^{b}$ & NS & NS & NS & NS & $19.0^{b}$ & NS & $27.0^{\mathrm{b}}$ \\
\hline$A D L$ & $20.7^{b}$ & NS & NS & NS & $17.9^{\mathrm{b}}$ & NS & $4.4^{\mathrm{a}}$ & $17.1^{b}$ & NS & $15.4^{b}$ \\
\hline \multicolumn{11}{|l|}{ Solubility } \\
\hline$A \cup F$ & NS & $72.2^{\mathrm{b}}$ & NS & $5.0^{\mathrm{a}}$ & NS & NS & NS & $171.1^{b}$ & NS & $14.4^{b}$ \\
\hline LGS & NS & $33.9^{b}$ & NS & $5.9^{a}$ & NS & NS & NS & $10.4^{b}$ & NS & $12.7^{b}$ \\
\hline$A P C$ & NS & $7.4^{\mathrm{a}}$ & $5.6^{\mathrm{a}}$ & NS & NS & NS & $4.7^{\mathrm{a}}$ & $7.5^{a}$ & NS & $9.1^{b}$ \\
\hline \multicolumn{11}{|c|}{ Digestibility } \\
\hline$O M$ & $34.4^{b}$ & $45.5^{\mathrm{b}}$ & $15.6^{\mathrm{b}}$ & NS & NS & NS & $12.7^{b}$ & $8.1^{b}$ & NS & $22.3^{b}$ \\
\hline$C F$ & $10.9^{b}$ & $6.4^{\mathrm{a}}$ & NS & NS & NS & NS & NS & NS & NS & NS \\
\hline
\end{tabular}

* For abbreviations, see table IV. NS: non significant; ${ }^{a}$ significant at $P=0.05{ }^{\circ}$ significant at $P=0.01$.

Appendix 4. Effect ( $F$ values) of year $(Y)$, location $(L)$ (Clermont-Ferrand, Lusignan, le Pin-au-Haras, La Jaillère) and dry matter content (DM) on chemical composition and nutritive value of hybrid 1.

\begin{tabular}{|c|c|c|c|c|c|c|c|}
\hline \multirow[t]{2}{*}{ Variates * } & \multicolumn{2}{|c|}{ Factorials } & \multicolumn{3}{|c|}{ Interactions } & \multicolumn{2}{|c|}{ Covariates } \\
\hline & $Y$ & $L$ & $Y \times L$ & $Y \times D M$ & $L \times D M$ & $D M$ & $D M^{2}$ \\
\hline$A S H$ & NS & $25.3^{b}$ & NS & NS & $3.6^{\mathrm{a}}$ & $11.5^{\mathrm{b}}$ & NS \\
\hline$C P$ & $74.1^{b}$ & $4.4^{a}$ & $8.5^{b}$ & NS & NS & NS & NS \\
\hline GRA & $21.4^{b}$ & NS & NS & NS & $4.0^{\mathrm{a}}$ & $13.8^{b}$ & $8.8^{b}$ \\
\hline$S T A$ & $25.8^{\mathrm{b}}$ & NS & NS & NS & $6.5^{b}$ & $8.9^{\mathrm{b}}$ & $5.9^{\mathrm{a}}$ \\
\hline WSC & NS & NS & $4.5^{\mathrm{a}}$ & $9.8^{b}$ & NS & $28.5^{\mathrm{b}}$ & NS \\
\hline$N D F$ & NS & $4.7^{b}$ & $7.2^{b}$ & NS & $6.3^{b}$ & $16.3^{b}$ & NS \\
\hline$A D F$ & $8.3^{b}$ & $3.0 \mathrm{a}$ & NS & NS & $5.3^{b}$ & $18.6^{b}$ & NS \\
\hline$C F$ & $4.8^{a}$ & $8.4^{\mathrm{b}}$ & NS & NS & $5.5^{\mathrm{b}}$ & $20.9^{b}$ & NS \\
\hline$A D L$ & $7.3^{a}$ & $3.1^{a}$ & $6.4^{b}$ & NS & $5.5^{\mathrm{b}}$ & $11.2^{b}$ & NS \\
\hline \multicolumn{8}{|l|}{ Solubility } \\
\hline$A \cup F$ & NS & $9.3^{b}$ & NS & NS & NS & $8.6^{b}$ & NS \\
\hline LGS & NS & $11.2^{b}$ & $6.4^{b}$ & NS & NS & $15.3^{b}$ & NS \\
\hline$A P C$ & NS & NS & $3.7^{\mathrm{a}}$ & NS & NS & $10.2^{b}$ & NS \\
\hline \multicolumn{8}{|l|}{ Digestibility } \\
\hline$O M$ & $21.7^{b}$ & $8.2^{b}$ & NS & NS & $4.4^{\mathrm{a}}$ & $10.1^{b}$ & NS \\
\hline$C F$ & $8.3^{b}$ & $3.2^{a}$ & NS & NS & NS & NS & NS \\
\hline
\end{tabular}

* For abbreviations, see table IV. NS: non significant; ${ }^{\text {a }}$ significant at $P=0.05$; $^{\text {b }}$ significant at $P=0.01$. 


\section{REFERENCES}

Andrieu J, Demarquilly C (1974) Valeur alimentaire du maïs fourrage. II. Influence du stade de végétation, de la variété, du peuplement, de l'enrichissement en épis et de l'addition d'urée sur la digestibilité et l'ingestibilité de l'ensilage de maïs. Ann Zootech 23, 1-25

Andrieu J (1975) Le maïs gelé fait un ensilage de moindre qualité. Rev élevage 36, 61

Andrieu J (1976) Factors influencing the composition and the nutritive value of ensiled whole crop maize. The maize crop as a basic feed for beef production. Anim Feed Sci Technol $1,381-392$

Andrieu J (1985) Composition et valeur alimentaire du maîs plante entière. In: Colloque Maiis Ensilage. Rennes, 29-30 May 1985

Aufrere J, Michalet-Doreau B (1983) In vivo digestibility and prediction of digestibility of some by-products. Feeding value of byproducts and their use by beef cattle. EEC Seminar. Gontrode, September 1983, 27-29

Barrière $Y$, Demarquilly $C$, Hebert $Y$, Dardenne $P$, Andrieu J, Maupetit P, Lila M, Emile JC (1991) Influence de la variabilité génétique et environnementale sur la digestibilité in vitro ou in vivo du maïs fourrage. Agronomie 3, 151-157

Buritt EA, Bittner AS, Street JC, Anderson MJ (1984) Correlations of phenolic acids and $x y-$ lose content of cell wall with in vitro dry matter digestibility of three maturing grasses. J Dairy Sci 67, 1209-1213

Dardenne $P$, Andrieu J, Barrière $Y$, Biston $R$, Demarquilly C, Femenias N, Lila M, Maupetit $P$, Rivière $F$, Ronsin TH (1993) Composition et valeur nutritive de la plante de maïs distribuée à l'état frais à des moutons. Il. Prévision de la digestibilité. Ann Zootech 42, 251270

Deinum B (1984) Measurement and prediction of digestibility of forage maize in the Netherlands. Anim Feed Sci Technol 10, 301-313

Demarquilly C (1969) Valeur alimentaire du maïs fourrage. I. Composition chimique et digestibilité du maïs sur pied. Ann Zootech 18, 17-32
Demarquilly C, Andrieu J (1973) Valeur nutritive et utilisation de la plante entière de maïs sur pied, ensilée ou déshydratée. In: 24th FEZ Annual Meeting. Vienne, 23-28 September 1973

Demarquilly C, Andrieu J, Sauvant D (1978) Composition et valeur nutritive des aliments. In: L'Alimentation des Ruminants. INRA Publications, $\mathrm{Ch} 17$

Dirven JPC, Deinum B (1977) The effect of temperature on the digestibility of grasses: an analysis. Forage Res 3, 1-7

Engels FM, Cones JW (1989) Cell Wall Structure, Composition and Digestibility. Wageningen Ede, November, 1989

Giger S, Sauvant D, Dorleans M, Morand-Fehr P (1979) Détermination semi-automatique des constituants membranaires des aliments concentrés par la méthode de Van Soest. In: 30th Animal Meeting of the European Association for Animal Production. Harrogate, UK, 23-26 July 1979

Jarrige R, Minson DJ (1964) Digestibilité des constituants du ray-grass anglais S24 et du dactyle S37, plus spécialement des constituants glucidiques. Ann Zootech 13, 117-150

Jung HG, Fahey GC (1984)) Influence of phenolic acids on forage structural carbohydrate digestion. Can J Anim Sci 64, 50-51

Lila M, Barrière $Y$, Traineau $R$ (1986) Mise au point et étude d'un test enzymatique de la digestibilité des fourrages pauvres ou riches en amidon. Agronomie 6, 285-291

Radley JA (1953) Starch and its Derivatives. Chapman and Hall, London, vol II, 3rd ed

Ragland JL, Hatfield AL, Benoit GR (1965) The growth and yield of corn. I. Microclimate effects on the growth rate. Agron J 57, 217220

Seebeck RM (1973) The effect of body weight loss on the composition of Brahman cross and Africaner cross steers. I. Empty body weight dressed carcass weight and of all components. J Agric Sci 80, 201-210

Somogyi (1952) Notes on sugar determination. J Biol Chem 195, 19-23

Struik PC (1983) Physiology of forage maize in relation to its production and quality. Doctoral thesis, Wageningen, pp 252

Struik PC, Deinum B, Hoefsloot JMP (1985) Effects of temperature during stages of devel- 
opment on growth and digestibility of forage maize. Neth J Agric Sci 33, 405-420

Thivend P, Mercier C, Guilbot A (1965) Dosage de l'amidon dans les milieux complexes. Ann Biol Anim Biochim Biophys 5, 513-526

Van Soest PJ (1967) Development of a comprehensive system of feed analysis and its application to forages. J Anim Sci 26, 119128

Van Soest PJ, Moore LA (1965) New chemical methods for analysis of forages for the purpose of predicting nutritive value. In: Proc IX Int Grassland Congr. Sao Paulo, Brazil, paper 424 